\title{
Characterization of the coccolithophore community off Cabo Verde archipelago, including the Senghor Seamount (Eastern North Atlantic)
}

\author{
Áurea Narciso ${ }^{\mathrm{a}, \mathrm{b}, \mathrm{c}, *}$, Jamileh Javidpour ${ }^{\mathrm{d}}$, Xupeng Chi ${ }^{\mathrm{e}}$, Mário Cachão ${ }^{\mathrm{f}, \mathrm{g}}$, \\ Manfred Kaufmann ${ }^{\text {a,b,c }}$ \\ a CIIMAR- Madeira, Caminho da Penteada, Funchal, Madeira, 9020-105, Portugal \\ ${ }^{\mathrm{b}}$ CIIMAR, University of Porto, Av. General Norton de Matos $s / n$, Matosinhos, 4450-208, Portugal \\ ${ }^{\mathrm{c}}$ University of Madeira, Faculty of Life Sciences, Marine Biology Station of Funchal, Funchal, 9000-107, Portugal \\ d University of Southern Denmark, Department of Biology, Campusvej 55, Odense, 5230, Denmark \\ e GEOMAR Helmholtz Centre for Ocean Research Kiel, Düsternbrooker Weg 20, Kiel, 24105, Germany \\ ${ }^{\mathrm{f}}$ Dom Luiz Institute, Faculty of Sciences, University of Lisbon, Lisboa, 1749-016, Portugal \\ ${ }^{\mathrm{g}}$ University of Lisbon, Faculty of Sciences, Department of Geology, Lisboa, 1749-016, Portugal
}

\section{A R T I C L E I N F O}

\section{Keywords:}

Extant coccolithophores

Biodiversity

Ecology

Seamount

Cyclonic eddy

Eastern subtropical Atlantic

\begin{abstract}
A B S T R A C T
A systematic investigation of the extant coccolithophore community around Cabo Verde archipelago was performed during the cruise MSM49 of RV Maria S. Merian, which took place in the late fall of 2015. The description of the spatial and vertical distributions of coccolithophores was based on a survey performed to the north, east and south of Cabo Verde archipelago, between the surface and $150 \mathrm{~m}$ water depth. The total cell densities obtained for the studied region were relatively low, reaching to a maximum of $30 \times 10^{3}$ cell $\mathrm{L}^{-1}$ in the upper $50 \mathrm{~m}$ over the southeastern slope of the Senghor seamount. Emiliania huxleyi and Gephyrocapsa oceanica were the dominant species, followed by Florisphaera profunda. The coccolithophore distribution off Cabo Verde was essentially explained by relatively warm and nutrient-depleted waters in the region during the surveyed interval, in result of the weaker NE trade winds and the northward migration of the Intertropical Convergence Zone. In these conditions, a notable zonation of coccolithophores along depth was depicted, in consequence of the inferred general well-stratified water column. Four typical depth-related groups were identified: (i) a Shallow oligotrophic (10-30 m), represented by Discosphaera tubifera and Umbellosphaera spp.; (ii) an Intermediate ( $40-50 \mathrm{~m}$ ), formed by the three placolith-bearing species E. huxleyi, G. ericsonii and G. oceanica, and by Algirosphaera robusta, Helicosphaera spp., Michaelsarsia spp., Syracosphaera spp. and Umbilicosphaera spp.; (iii) a Deep (60-75 m) with F. profunda, Ophiaster spp., Oolithotus spp. and Reticulofenestra sessilis as typical members; (iv) and The Deepest $(>80 \mathrm{~m})$, composed by Gladiolithus flabellatus and Syracosphaera lamina. In addition, high abundances of $G$. oceanica related with the Eddy station were attributed to the transport and thriving of the coastal coccolithophore community, dominated by this species, from the African coast towards Cabo Verde.
\end{abstract}

\section{Introduction}

The eastern subtropical North Atlantic is an oligotrophic to mesotrophic region, bordered to the west and north by the oligotrophic subtropical gyre, to the east by the NW African coast, with frequent formation of eddies and filaments transporting upwelled nutrient-rich water from the coast offshore, and to the south by the equatorial convergence also often transporting upwelled waters towards Cabo Verde. In addition, an increase in nutrients in the proximity of an island, known as Island Mass Effect (IME), may rise the nearshore standing stock of phytoplankton biomass by more than $80 \%$ over background oceanic productivity (Gove et al., 2016). Acting as natural barriers in the main current pathways, seamounts lead to similar geophysical and biological effects when compared to the surrounding open ocean (Heywood et al., 1990; Hasegawa et al., 2004). The movement of water masses around these prominent features of seabed, usually associated with the upwelling of nutrient-rich deep sea water, lead to a higher primary production and the subsequent increase of fauna and flora around the peaks (Abecasis et al., 2009), thus considered hotspots of biodiversity (Morato et al., 2010). However, at Senghor seamount in

\footnotetext{
* Corresponding author. CIIMAR- Madeira, Caminho da Penteada, Funchal, Madeira, 9020-105, Portugal.

E-mail address: aurea.narciso@staff.uma.pt (Á. Narciso).
} 
particular, studies focused on zooplankton distribution patterns showed no significant differences between seamount and open sites (Denda and Christiansen, 2014). Similarly, the seamount effect on the trophic structure of zooplankton and micronekton communities was weak (Denda et al., 2017a). Since short residence times are known for phytoplankton stocks over seamounts (Mendonça et al., 2012), a detailed study focusing on spatial and temporal composition and distribution of phytoplankton throughout this topographic feature is still vital to clearly understand its dynamics.

With respect to regional investigations, they exist on integral ecological aspects related to the Cape Verde Frontal Zone (Zenk et al., 1991), upwelling filaments formed in the NW African coast (Meunier et al., 2012) and impact of Saharan dust reaching the area (Baker et al., 2007; Marañón et al., 2010). Other studies have already focused on taxonomic composition and distribution of zooplankton (Denda and Christiansen, 2014; Denda et al., 2017) but, concerning the phytoplankton community and taxonomy, only few works based on sediment traps have evaluated the coccolithophore dynamics in this regional context (Köbrich and Baumann, 2009; Köbrich et al., 2015; Guerreiro et al., 2019; Romero et al., 2019).

Coccolithophores, which represent about $10 \%$ of the global phytoplankton biomass (Tyrrell and Young, 2009), are pelagic unicellular algae, members of the haptophyte class Prymnesiophyceae Hibberd, distinguished by the ability to produce calcite platelets. These structures, referred as coccoliths, surround the living cell and form an exoskeleton called coccosphere (e.g. Winter and Siesser, 1994; Young, 1994). These phytoplankton organisms, with its first appearance in Upper Triassic sediments (Bown et al., 2004), are widely and abundantly distributed in the ocean, being one of the major contributors of pelagic carbonate on Earth (Honjo, 1996; Schiebel, 2002; Beare et al., 2013). Through biomineralization and photoautotrophy, coccolithophores influence the global carbon and sulphur cycles, actively participating in the climate system (Westbroek et al., 1993; Rost and Riebesell, 2004; Taylor et al., 2007). This fact has aroused much concern about the response of coccolithophores to climate change and subsequent ocean acidification (e.g. Oviedo et al., 2015; 2017; D'Amario et al., 2017; Smith et al., 2017).

The present study, focusing on the spatial and temporal composition and distribution of coccolithophores off Cabo Verde, aims to: i) determine the main coccolithophore contributors to the marine phytoplankton community and their overall response to the regional hydrography and physico-chemical parameters; ii) identify the preferential development along the water column relative to nutricline, that compose the upper and lower photic zone assemblages; iii) detail specific species preferences in response to the variety of ecological niches sampled; iv) understand the role of the Senghor seamount in the coccolithophore distribution.

\section{Oceanographic setting}

The study area is located around Cabo Verde islands, between $12^{\circ}$ $18^{\circ} \mathrm{N}$ and $20^{\circ}-24^{\circ} \mathrm{W}$, including the Senghor seamount, locally also known as Nova Holanda seamount. It consists in a nearly conical seamount, which rises from $3300 \mathrm{~m}$ to a small summit plateau with a minimum depth of approximately $100 \mathrm{~m}$. This area is influenced hydrographically by large-scale interactions between the Canary Current (CC), the North Equatorial Current (NEC) and the North Equatorial Countercurrent (NECC), forming the Cape Verde Frontal Zone (CVFZ) that is associated with potentially productive zones (Fernandes et al., 2005) (Fig. 1). This feature extends, with some seasonal variability, from Cape Blanc to the SW close to the north-western islands of the archipelago (Pérez-Rodríguez et al., 2001; Vangriesheim et al., 2003). The NEC is originated from the CC when its flux turns southwestwards leaving the African continent. This current, formed in the north of the Cabo Verde islands, is a westerly flow directly responding to the NE trade winds (Stramma et al., 2005). Between $5^{\circ} \mathrm{N}$ and $10^{\circ} \mathrm{N}$ the dominant surface feature is the NECC. This weaker and easterly current curves northwards close to the African coast to form the Mauritanian Current (MC) (Mittelstaedt, 1991).

The boundary between the NE and SE trade winds corresponds to the Intertropical Convergence Zone (ITCZ), located around $6^{\circ} \mathrm{N}$ in February and $15^{\circ} \mathrm{N}$ in August, in response to insolation received by the African continent (Molinari et al., 1986). During boreal summer and autumn, when the northernmost position of the ITCZ is observed, the stronger SE trade winds produce an increase in the NECC velocity and a weakening of the NEC and the CC (Mittelstaedt, 1991; Peterson and Stramma, 1991;
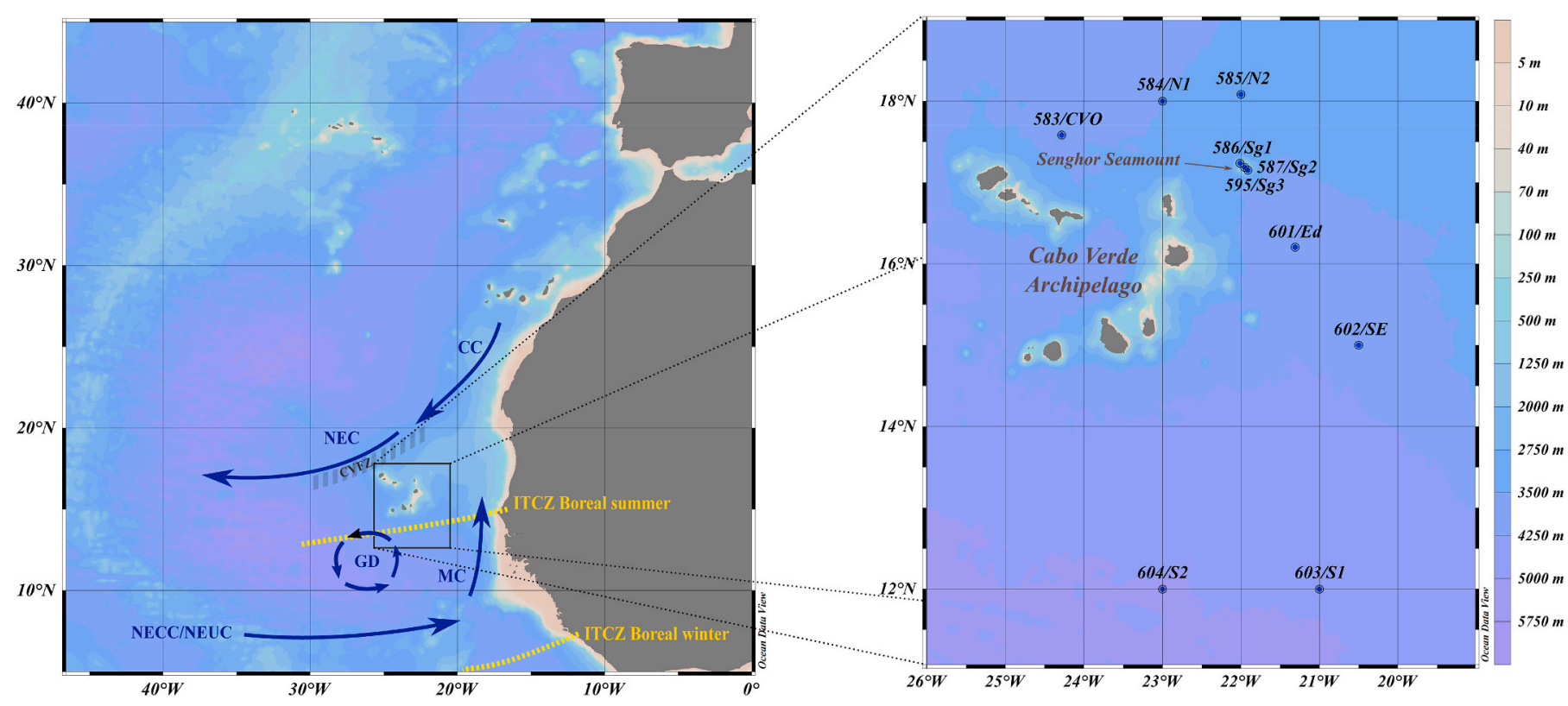

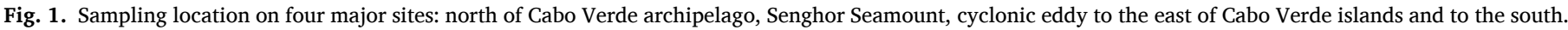

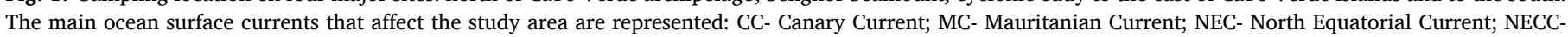

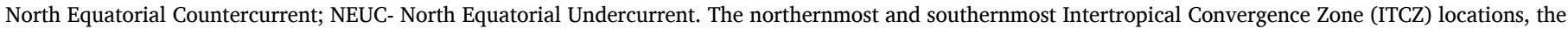
Guinea Dome (GD) and the Cape Verde Frontal Zone (CVFZ) are also included. 
Stramma et al., 2005). When the strengthening of the NECC occurs, the warm oligotrophic equatorial waters of the MC reach further north at about $20^{\circ} \mathrm{N}$, suppressing the coastal upwelling south of this latitude (Mittelstaedt, 1991).

South of the Cabo Verde archipelago and associated with a cyclonic circulation is the Guinea Dome (GD) (Mazeika, 1967). This quasi stationary feature is part of the large-scale near-surface flow fields associated with the NEC, NECC, as well as with the North Equatorial Undercurrent (NEUC) (Siedler et al., 1992). The GD develops seasonally due to the wind-induced Ekman upwelling associated with the northwards migration of the ITCZ (Doi et al., 2009), similar to the seasonal changes in the NECC (Fernandes et al., 2005).

\section{Material and methods}

\subsection{Sample collection}

Sampling was performed during the oceanographic campaign MSM49 onboard of the RV Maria S. Merian, between 28 of November and December 21st, 2015, in the scope of the project SEAMOX-the Influence of Seamounts and Oxygen Minimum on Pelagic Fauna in the Eastern Tropical Atlantic (Christiansen et al., 2016).

Within the scope of our study, a total of 10 stations to the north, east and south of the Cabo Verde archipelago were sampled (Fig. 1, Table 1). Among these stations there is the Cabo Verde Ocean Observatory (CVOO; St. 583) at the north, the Senghor summit and middle slopes (Sts. 587, 586, 595), a cyclonic eddy (St. 601) at the east, and oceanic stations (Sts. 602, 603, 604) at the south. Stations 585 and 602 were also considered as reference stations for the Senghor seamount and the eddy, respectively. To easily localize the stations in the ocean, we adopted the following denominations: CVO (583), N1 (584), N2 (585), Sg1 (586), Sg2 (587), Sg3 (595), Ed (601), SE (602), S1 (603) and S2 (604).

Seawater samples were collected between 6 and 9 depths per station, from the first $150 \mathrm{~m}$, through a CTD/Rosette system equipped with 24 Niskin bottles of $10 \mathrm{~L}$ volume. The water column was sampled for physical, chemical and biological data using a Seabird CTD (SBE911 plus) incorporated with conductivity, temperature and dissolved oxygen sensors (all SEA-BIRD ELECTRONICS), as well as a combined fluorescence/turbidity sensor (WET LABS, ECO-FL-NTU).

\subsection{Physico-chemical parameters}

In situ temperature and conductivity were measured with a Seabird CTD (SBE911 plus), with accuracies of $\pm 0.001{ }^{\circ} \mathrm{C}$ for temperature and

Table 1

Geographical coordinates, date and sampling depths of MSM49 stations.

\begin{tabular}{|c|c|c|c|c|c|}
\hline \multicolumn{2}{|c|}{ Station } & \multirow{2}{*}{$\frac{\text { Latitude }}{17.583}$} & \multirow{2}{*}{$\begin{array}{l}\text { Longitude } \\
-24.284\end{array}$} & \multirow{2}{*}{$\begin{array}{l}\text { Date } \\
\begin{array}{l}\text { December 01, } \\
2015\end{array}\end{array}$} & \multirow{2}{*}{$\begin{array}{l}\text { Sampling depths (m) } \\
\begin{array}{l}10,25,50,75,100, \\
125,150\end{array}\end{array}$} \\
\hline 583 & CVO & & & & \\
\hline 584 & N1 & 18.000 & -23.000 & $\begin{array}{l}\text { December 03, } \\
2015\end{array}$ & $\begin{array}{l}15,30,40,50,60,80 \\
100,125,150\end{array}$ \\
\hline 585 & N2 & 18.083 & -22.000 & $\begin{array}{l}\text { December 05, } \\
2015\end{array}$ & $\begin{array}{l}15,40,55,60,75,80 \\
100,125,150\end{array}$ \\
\hline 586 & Sg1 & 17.237 & -22.012 & $\begin{array}{l}\text { December 06, } \\
2015\end{array}$ & $\begin{array}{l}15,40,50,60,80,100, \\
125,150\end{array}$ \\
\hline 587 & $\mathrm{Sg} 2$ & 17.188 & -21.954 & $\begin{array}{l}\text { December 07, } \\
2015\end{array}$ & $20,40,50,60,80,90$ \\
\hline 595 & Sg3 & 17.152 & -21.912 & $\begin{array}{l}\text { December 09, } \\
2015\end{array}$ & $\begin{array}{l}20,40,50,70,80,100, \\
125,150\end{array}$ \\
\hline 601 & Ed & 16.203 & -21.309 & $\begin{array}{l}\text { December 11, } \\
2015\end{array}$ & $\begin{array}{l}20,40,50,60,80,100 \\
125,150\end{array}$ \\
\hline 602 & SE & 15.000 & -20.500 & $\begin{array}{l}\text { December 14, } \\
2015\end{array}$ & $\begin{array}{l}15,30,40,60,80,100, \\
125,150\end{array}$ \\
\hline 603 & S1 & 12.000 & -21.000 & $\begin{array}{l}\text { December 16, } \\
2015\end{array}$ & $\begin{array}{l}15,40,50,60,80,100 \\
125,150\end{array}$ \\
\hline 604 & $\mathrm{~S} 2$ & 12.000 & -23.000 & $\begin{array}{l}\text { December 19, } \\
2015\end{array}$ & $\begin{array}{l}15,40,50,60,80,100, \\
125,150\end{array}$ \\
\hline
\end{tabular}

$\pm 0.0003 \mathrm{~S} \mathrm{~m}^{-1}$ for conductivity. Practical salinity and density were converted from temperature, conductivity and depth measurements.

Fluorescence was measured with a WET LABS, ECO FLNTU sensor with a sensitivity of $0.025 \mathrm{mg} \mathrm{m}^{-3}$.

Dissolved oxygen (DO) sensor data were calibrated using water samples drawn at 12 stations and analyzed by Winkler titration for dissolved oxygen.

All raw CTD data were processed following the GO-SHIP guidelines for the SBE 911 plus (e.g Hood et al., 2010). Visualization of the physical data was done using Ocean Data View software (Schlitzer, 2020). The hydrographic data are available at the PANGAEA database (Kaufmann et al., 2020).

Samples for dissolved inorganic nutrients $\left(\mathrm{PO}_{4}, \mathrm{NO}_{2}, \mathrm{NO}_{3}\right.$ and $\mathrm{SiO}_{4}$ $\left(\mu \mathrm{mol} \mathrm{L}{ }^{-1}\right)$ ) were taken together with the phytoplankton samples. Water samples (volume depending on plankton abundance) were filtered through pre-washed $(10 \% \mathrm{HCl})$ cellulose acetate filters (Sartorius, 0.2 $\mu \mathrm{m}$ pore size) and frozen immediately until analysis. Samples were measured following the protocols of Hansen and Koroleff (1999) with an auto-analyzer (Skalar, SANPLUS; Breda/Netherlands). The detection limit of the auto-analyzer was at a concentration of $0.1 \mu \mathrm{mol} \mathrm{L}^{-1}$.

\subsection{Coccolithophores}

A total of 79 samples were collected for coccolithophore analysis. Onboard, between 4 and $5 \mathrm{~L}$ of water were immediately filtered through Whatman nuclepore track-etched polycarbonate membranes $(0.4 \mu \mathrm{m}$ pore size, $47 \mathrm{~mm}$ diameter), using low vacuum suction (200-400 mbar), for identification and quantification of this phytoplankton group. The filters were rinsed with about $1-2 \mathrm{ml}$ of deionized water, to remove sea salt, and left to dry in petri dishes at room temperature. On land, at the lab, a randomly chosen 20 to $30^{\circ}$ angular sector of each filter was cut and permanently mounted on a slide using Entellan mounting media and a cover slip. Species diversity and abundances were determined under cross-polarized light microscopy (Leitz Ortholux II Pol-BK) at 1250x magnification. At least 400 coccospheres were counted through a randomly selected sequence of fields of view (FOV) aligned parallel to the radius of the filter. For samples with the lowest abundances (depths below $100 \mathrm{~m}$ ), in which the density of coccospheres was much lower, the total screened area per filter reached around $10 \mathrm{~mm}^{2}$ (equivalent to 430 FOV). The absolute abundances (Coccosphere $\mathrm{L}^{-1}$ ) were estimated as follows:

Coccosphere $\mathrm{L}^{-1}=[N \mathrm{x}(T A / E A)] / V$. Where $N$ refers to the number of counted coccospheres in the examined area, $T A$ is the total filter area, $E A$ the examined area and $V$ the volume of filtered water.

Identification of coccolithophores was performed according to Cros and Fortuño (2002), Young et al. (2003), Jordan et al. (2004) and Frada et al. (2010).

\subsection{Multivariate analysis}

To evaluate the ecological similarities among coccolithophore taxa and their relationship with the environmental conditions, a Canonical Correspondence Analysis (CCA) was conducted using the software package PAleontological STatistics (PAST) vers. 4.0 (Hammer et al., 2001). In order to minimize variance dispersion a square root transform was applied to the data matrix composed of 27 variables (columns) and 79 samples (rows), prior to the multivariate analysis. Ten environmental parameters were determined: water density, depth, fluorescence, dissolved oxygen, salinity, temperature, nitrate, nitrite, phosphate and dissolved silicate. From the microbiological water column analysis, 16 of the more relevant coccolithophore taxa (see criteria in section 4.2.1) were selected as dependent variables in addition to the total coccolithophore absolute abundance for the CCA analysis. 


\section{Results}

\subsection{Physico-chemical parameters}

The maximum temperature, registered around the upper $30 \mathrm{~m}$, varied between $24.5^{\circ} \mathrm{C}$ at the SE slope of the Senghor seamount (Sg3) and $27.4{ }^{\circ} \mathrm{C}$ at the southernmost station $\mathrm{S} 1$. The minimum temperature of the studied surface layer was observed at $150 \mathrm{~m}$ depth, varying between $12.9^{\circ} \mathrm{C}$ at the southernmost station S2 and $14.9^{\circ} \mathrm{C}$ at station $\mathrm{N} 2$. Stations S1, S2 and SE showed a homogeneous surface layer in the upper 25-30 m, whereas in the other stations the homogeneous surface layer was observed down to $35-50 \mathrm{~m}$. Stations Sg3 and N2 recorded the deepest thermocline (Fig. 2, Table 2).

In the upper $30 \mathrm{~m}$ of the homogeneous surface layer the salinity varied between 35.4 (S1) and 36.3 (CVO). Maximum values, between 35.7 ( $\mathrm{S} 1$ ) and 36.4 (CVO), were recorded at the thermocline for the several sites. Below this depth a general salinity decrease was observed until the lowest depth recorded.

The vertical profile of density is similar to that of the temperature, with the pycnocline around 25-45 $\mathrm{m}$ at S1, S2 and SE and around 45-65 $\mathrm{m}$ for the other stations. The deepest and the greatest density gradient were recorded at the SE slope of the Senghor seamount (Sg3).
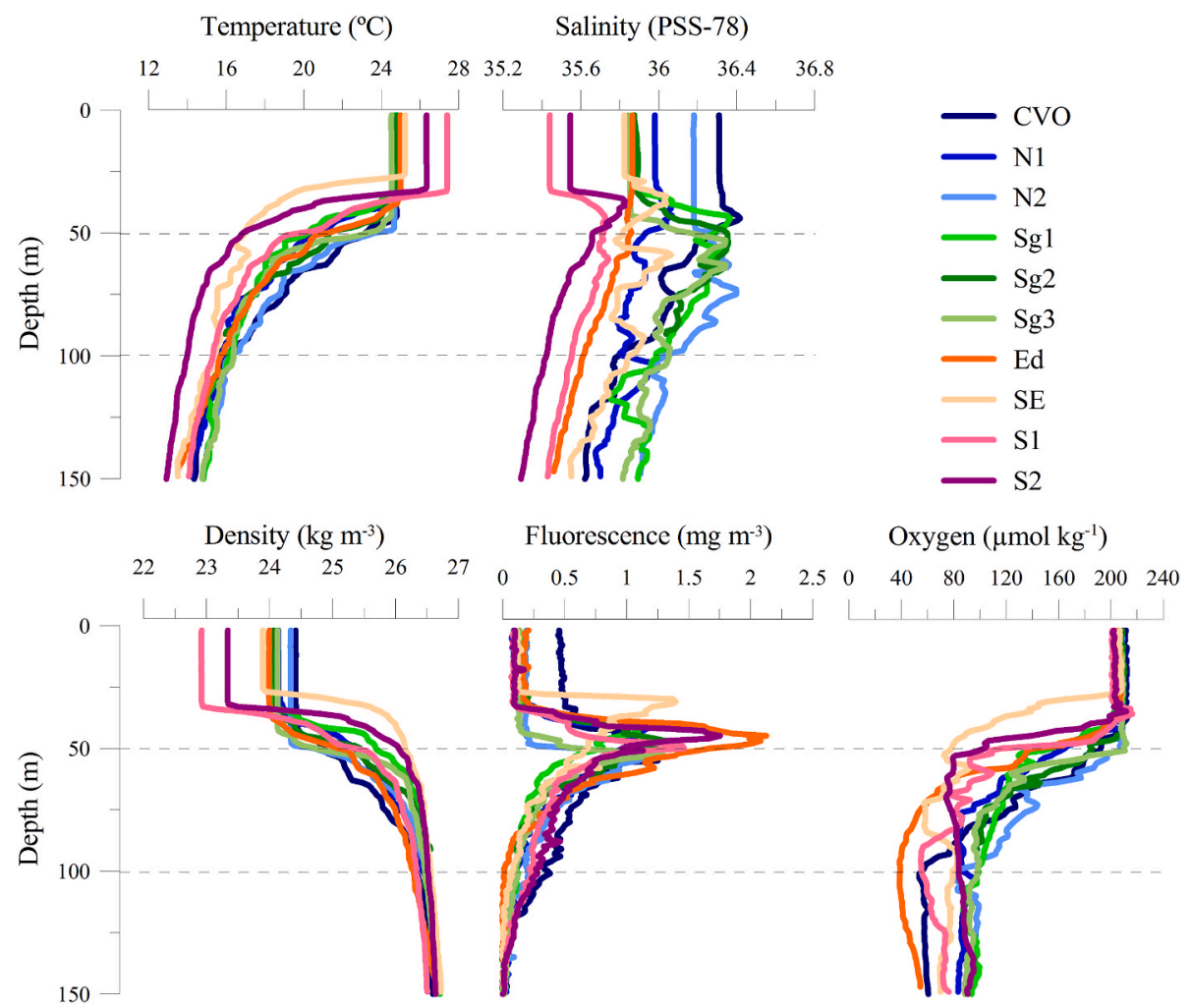

Fig. 2. Physico-chemical parameters distribution (Temperature, salinity, density, fluorescence and dissolved oxygen) along the uppermost $150 \mathrm{~m}$ water depth for the 10 stations.

Table 2

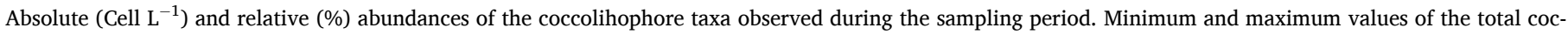
colithophores and the physico-chemical parameters are also indicated.

\begin{tabular}{|c|c|c|c|c|c|c|}
\hline \multirow[t]{2}{*}{ Taxa } & \multicolumn{2}{|l|}{ Cell L ${ }^{-1}$} & \multirow[t]{2}{*}{$\%$} & \multirow[t]{2}{*}{ Parameters } & \multirow[t]{2}{*}{ Min } & \multirow[t]{2}{*}{ Max } \\
\hline & Mean & Max & & & & \\
\hline Emiliania huxleyi & 2373.90 & 14375.00 & 36.38 & Density $\left(\mathrm{kg} \mathrm{m}-{ }^{3}\right)$ & 22.921 & 26.718 \\
\hline Gephyrocapsa ericsonii & 479.93 & 4641.07 & 7.36 & Fluorescence $\left(\mathrm{mg} \mathrm{m}^{3}\right)$ & 0.000 & 2.075 \\
\hline Gephyrocapsa oceanica & 1280.44 & 8231.58 & 19.62 & Oxygen $\left(\mu \mathrm{mol} \mathrm{kg}{ }^{-1}\right)$ & 38.740 & 212.190 \\
\hline Reticulofenestra sessilis & 20.33 & 624.91 & 0.31 & Salinity (PSS-78) & 35.113 & 36.399 \\
\hline Algirosphaera robusta & 231.84 & 2435.29 & 3.55 & Temperature $\left({ }^{\circ} \mathrm{C}\right)$ & 12.916 & 27.303 \\
\hline Discosphaera tubifera & 62.58 & 868.89 & 0.96 & Nitrate $\left(\mu \mathrm{mol} \mathrm{L}^{-1}\right)$ & 0.200 & 29.650 \\
\hline Florisphaera profunda & 1156.88 & 7411.11 & 17.70 & Nitrite $\left(\mu \mathrm{mol} \mathrm{L}^{-1}\right)$ & 0.000 & 0.450 \\
\hline Gladiolithus flabellatus & 16.29 & 164.78 & 0.25 & Phosphate $\left(\mu \mathrm{mol} \mathrm{L}^{-1}\right)$ & 0.060 & 1.780 \\
\hline Helicosphaera spp. & 191.84 & 1328.89 & 2.94 & Silicate $\left(\mu \mathrm{mol} \mathrm{L}^{-1}\right)$ & 0.000 & 6.330 \\
\hline Oolithotus spp. & 94.33 & 1124.44 & 1.45 & & & \\
\hline Ophiaster spp. & 63.10 & 616.07 & 0.97 & & & \\
\hline Michaelsarsia spp. & 38.13 & 1073.33 & 0.58 & & & \\
\hline Syracosphaera spp. & 183.88 & 871.58 & 3.11 & & & \\
\hline Syracosphaera lamina & 25.23 & 256.74 & 0.39 & & & \\
\hline Umbellosphaera spp. & 176.74 & 3731.11 & 2.71 & & & \\
\hline \multirow[t]{2}{*}{ Umbilicosphaera spp. } & 53.33 & 427.14 & 0.82 & & & \\
\hline & Min & $\operatorname{Max}$ & & & & \\
\hline Total coccospheres (cell $\mathrm{L}^{-1}$ ) & 488.16 & 30064.29 & & & & \\
\hline
\end{tabular}



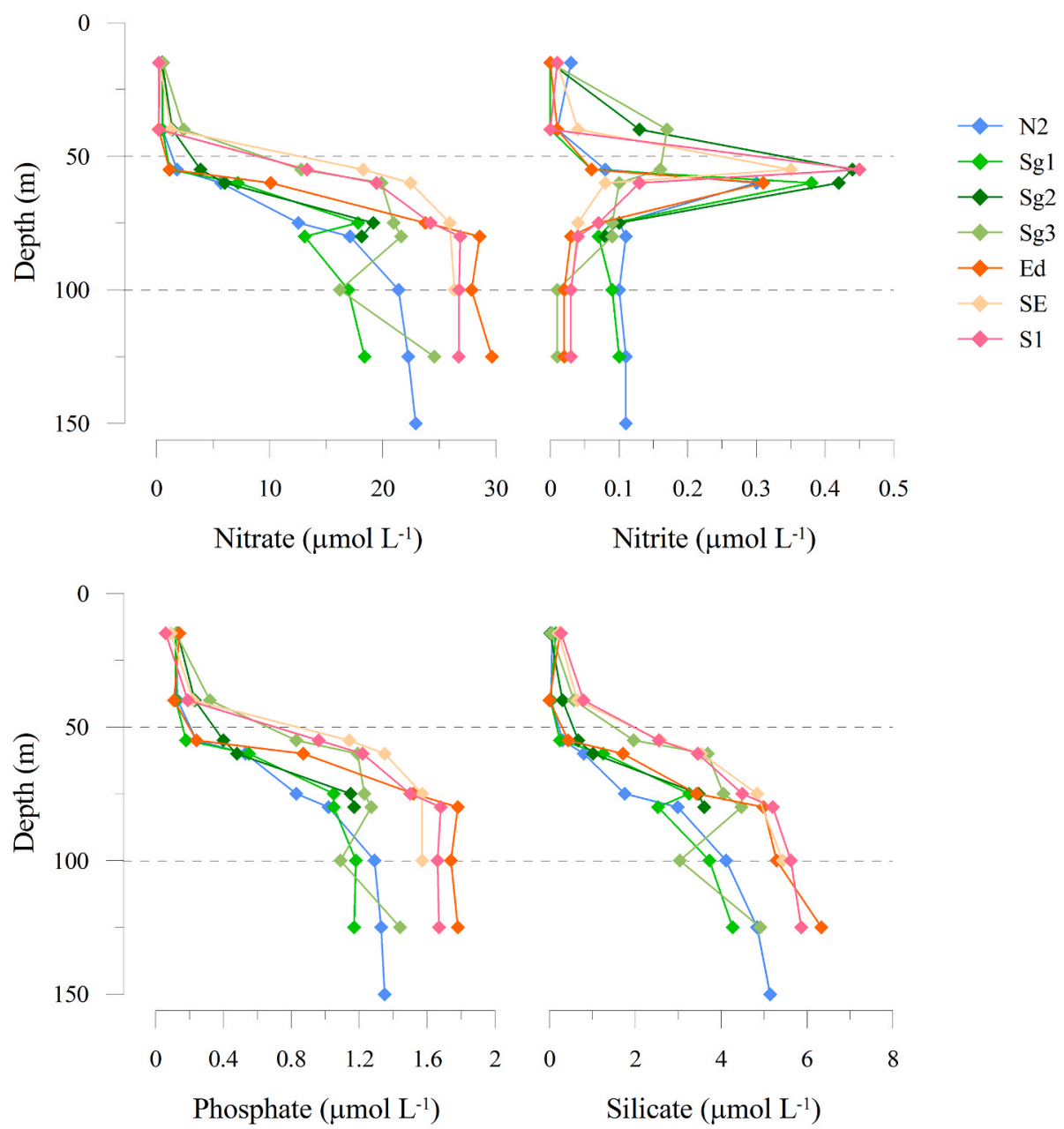

Fig. 3. Nutrient concentrations along the uppermost $150 \mathrm{~m}$ water depth for 7 stations. There are no data corresponding to the stations CVO, N1 and S2.

Fluorescence, as an indicator for phytoplankton biomass, showed the highest values at about $50 \mathrm{~m}$ for most of the stations, with exception of $\mathrm{SE}$, at which the maximum occurred at $30 \mathrm{~m}$. Moreover, the station Ed recorded the highest maximum values of fluorescence whereas the station in the NW slope of the Senghor seamount (Sg1) recorded the lowest.

Concerning the dissolved oxygen, a well-mixed saturated surface layer followed by a steep decline coincident with the fluorescence maximum was inferred. At stations Sg3 and N2 this decline started deeper, below the $50 \mathrm{~m}$ depth. From there and down to $150 \mathrm{~m}$, steady low oxygen levels were recorded for all stations.

Nitrate, phosphate and dissolved silicate show a general similar pattern along the upper $150 \mathrm{~m}$ of the water column, for the 7 surveyed locations (Fig. 3). Thus, nutrient levels were depleted at surface with significant increases from $40-55 \mathrm{~m}-80 \mathrm{~m}$ depth and slight increases

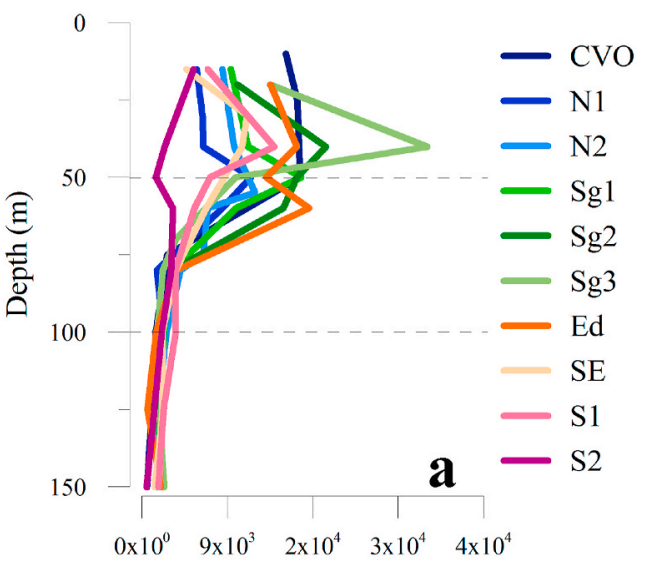

Total cell $\mathrm{L}^{-1}$

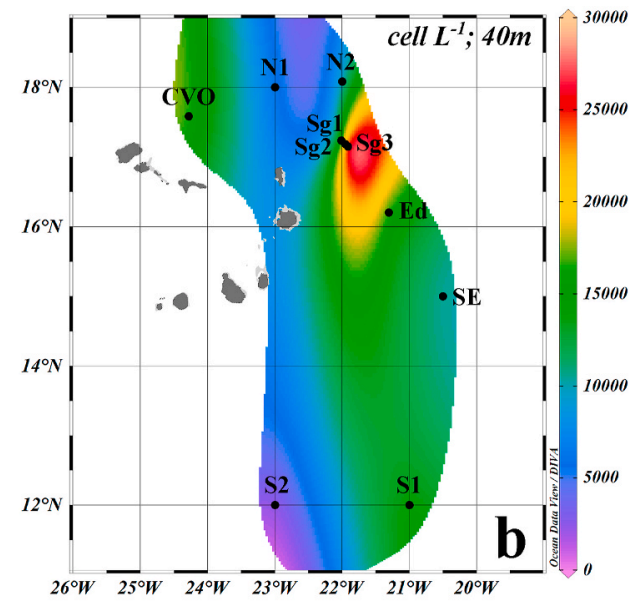

Fig. 4. Vertical distribution of total coccolithophores along the uppermost $150 \mathrm{~m}$ water depth for the 10 stations (a) and the isosurface map showing the spatial distribution of total coccolithophores around Cabo Verde archipelago at $40 \mathrm{~m}$ (b). 

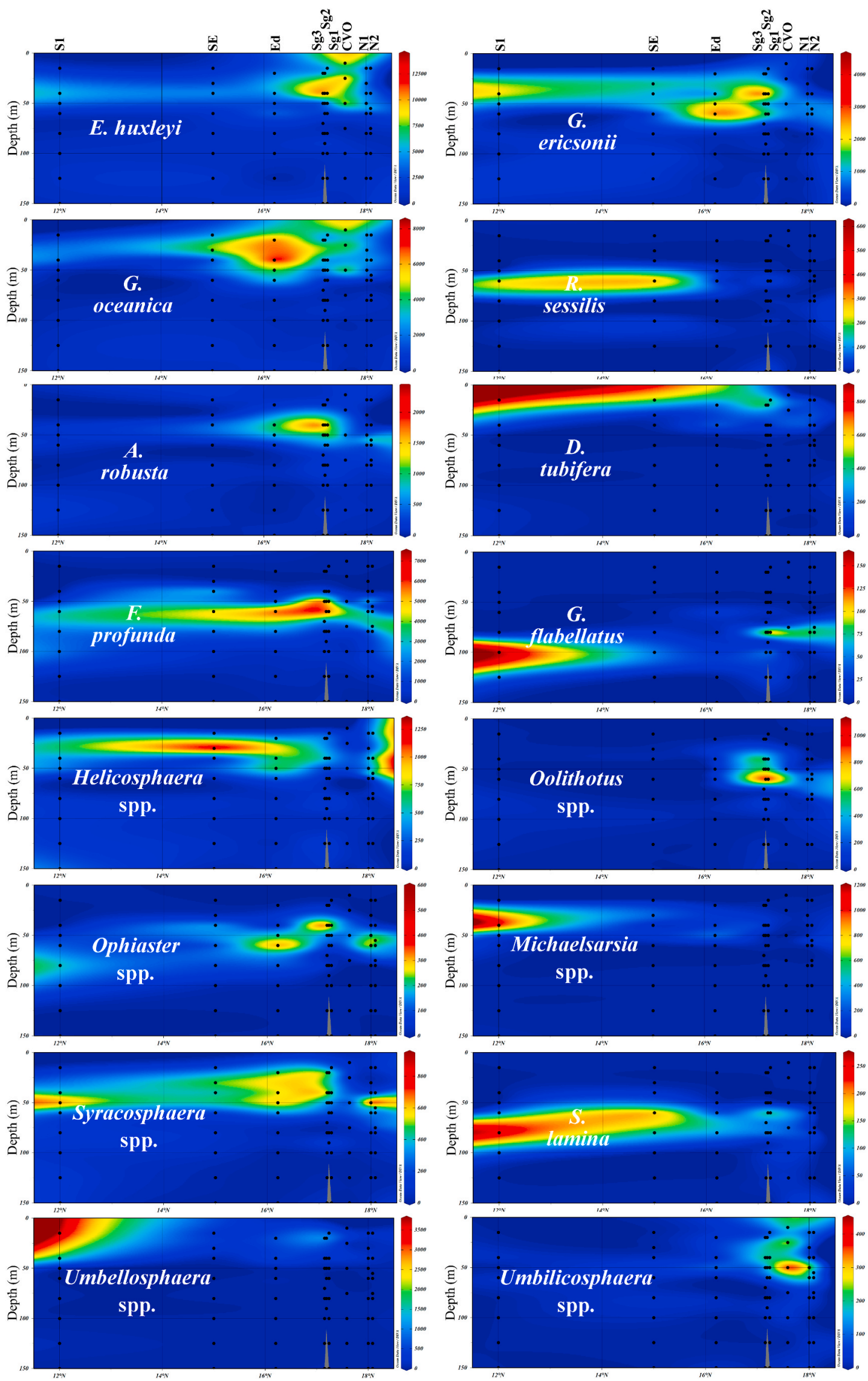

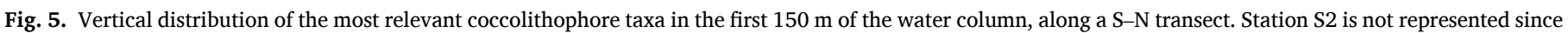
it would be overlapped to S1 and its absolute abundances are too low when compared with the other sites. 
below $100 \mathrm{~m}$. Nitrate and phosphate reach maximum values in the Ed station whereas silicate in the Ed and in the southern stations. Nitrite shows a different pattern with concentration peaks around 40-60 m depth, more pronounced in the southern station S1 and at the top of the Senghor seamount $(\mathrm{Sg} 2)$.

\subsection{Coccolithophores}

\subsubsection{Diversity and abundance of total coccolithophores}

Coccolithophores were well preserved and represented in the analyzed samples. A total of 39 distinct taxa were recognized using polarizing light microscopy, 2 identified to genus level and 37 to species level. Additional SEM analysis revealed more 7 species belonging to the genus Syracosphaera and 2 species to the genus Ophiaster. The complete list of taxa, including the rare ones and the species found at least once (*), can be consulted in the Appendix.

Total absolute abundances ranged between $0.49 \times 10^{3}$ and $30.06 \times$ $10^{3}$ cell $\mathrm{L}^{-1}$, being Emiliania huxleyi (morphotype type A) and Gephyrocapsa oceanica the dominant species, together making up to $56 \%$ of the total (Table 2). Although Bendif et al. (2019) have recently proposed that E. huxleyi and G. oceanica should be included in the genus Gephyrocapsa based on genome analysis, in the present study we preferred using the traditional taxonomic designation. The other relevant taxa for the present study, in order of decreasing abundance were: Florisphaera profunda, Gephyrocapsa ericsonii, Algirosphaera robusta, Syracosphaera spp., Helicosphaera spp. (mostly H. carteri), Umbellosphaera spp., Oolithotus spp. (mostly O. antillarum), Ophiaster spp., Discosphaera tubifera, Umbilicosphaera spp. (mostly U. sibogae), Michaelsarsia spp., Syracosphaera lamina, Reticulofenestra sessilis and Gladiolithus flabellatus. The relative abundances of the considered taxa were $>2 \%$ in at least five samples and $>0.3 \%$ of the total coccolithophores. However, since they are representative of certain depths, they were included in the study. The absolute abundances of these coccolithophores per sample are available at the PANGAEA database (Narciso et al., 2020).

The highest total abundances were observed at the southeastern slope of the Senghor seamount (Sg3), at a water depth of $40 \mathrm{~m}$, whereas the lowest coccolithophore abundances were observed at one of the southernmost stations, S2 (Fig. 4).

\subsubsection{Vertical distribution of the most relevant taxa}

A remarkable zonation can be inferred by coccolithophore depth distribution (Fig. 5). D. tubifera and Umbellosphaera spp. show the highest occurrences between depths of 15-20 m. The group formed by E. huxleyi, G. oceanica, G. ericsonii, A. robusta, Helicosphaera spp. and Michaelsarsia spp. present the major concentrations between 40 and 50 $\mathrm{m}$, although $G$. ericsonii also exhibits a peak at $60 \mathrm{~m}$. Syracosphaera spp. and Umbilicosphaera spp. show the major increases around $50 \mathrm{~m}$. The group composed by R. sessilis, F. profunda, Oolithotus spp. and Ophiaster spp. display the highest occurrences around $60 \mathrm{~m}$. S. lamina shows the major increase around $80 \mathrm{~m}$ whereas G. flabellatus shows it between 80 and $100 \mathrm{~m}$. Tracking this vertical distribution we may consider four main coccolithophore groups: a Shallow (SG) one, composed by D. tubifera and Umbellosphaera spp., linked to shallower waters above the thermocline; an Intermediate Group (IG), composed by E. huxleyi, G. oceanica, G. ericsonii, A. robusta, Helicosphaera spp., Michaelsarsia spp., Syracosphaera spp. and Umbilicosphaera spp., and more associated with the thermocline; a Deep Group (DG), formed by R. sessilis, F. profunda, Oolithotus spp. and Ophiaster spp., showing clear affinities with the nutricline; and The Deepest (TDG), formed by S. lamina and G. flabellatus (Table 3, Plate 1).

\subsubsection{Distribution of the most relevant taxa per station}

The analysis of Fig. 5 also indicates that the majority of these taxa occur mainly associated with the Senghor seamount stations. However, maxima increases of $D$. tubifera and Umbellosphaera spp., belonging to the shallow group, of $G$. flabellatus and S. lamina, from the deepest one,
Table 3

Depth-related groups from Cabo Verde and the relative abundance of each taxon in the associated water depth.

\begin{tabular}{|c|c|c|c|}
\hline \multirow[t]{2}{*}{ Groups } & \multirow{2}{*}{$\frac{\text { Typical water depth }}{(\mathrm{m})}$} & \multirow[t]{2}{*}{ Taxa } & \multirow{2}{*}{$\frac{\text { Relative abundance }}{(\%)}$} \\
\hline & & & \\
\hline \multirow[t]{2}{*}{ Shallow } & \multirow[t]{2}{*}{$10-30$} & Umbellosphaera spp. & 80 \\
\hline & & D. tubifera & 70 \\
\hline \multirow[t]{8}{*}{ Intermediate } & \multirow[t]{8}{*}{$40-50$} & E. huxleyi & 47 \\
\hline & & G. ericsonii & 54 \\
\hline & & G. oceanica & 43 \\
\hline & & A. robusta & 65 \\
\hline & & Helicosphaera spp. & 45 \\
\hline & & Michaelsarsia spp. & 80 \\
\hline & & Syracosphaera spp. & 47 \\
\hline & & Umbilicosphaera spp. & 50 \\
\hline \multirow[t]{4}{*}{ Deep } & \multirow[t]{4}{*}{$60-75$} & R. sessilis & 77 \\
\hline & & F. profunda & 42 \\
\hline & & Oolithotus spp. & 41 \\
\hline & & Ophiaster spp. & 37 \\
\hline \multirow[t]{2}{*}{ The Deepest } & \multirow[t]{2}{*}{$>80$} & S. lamina & 56 \\
\hline & & G. flabellatus & 88 \\
\hline
\end{tabular}

as well as of Michaelsarsia spp. are observed at the southernmost station $S 1$. Other exceptions are $G$. oceanica with the major abundances recorded in the station Ed, Helicosphaera spp. in the SE, R. sessilis in S2 (not shown in Fig. 5) and Umbilicosphaera spp. in the northern station CVO.

\subsection{Multivariate analysis}

The first three components of Canonical Correspondence Analysis (CCA) explained $94 \%$ of total data variability, with the first component (CCA 1 ) containing $72.4 \%$ and the second (CCA 2) $16.2 \%$ of total information (Fig. 6). The eigenvalues and its percentage variance are depicted in Table 4 whereas the loadings of each variable can be consulted in Table 5. Environmental variables and the direction of its maximum change are indicated by vectors, which length is proportional to the rate of change among samples. CCA 1 is mostly represented by the opposition between temperature and dissolved oxygen, in the negative semi-axis, and density, nutrients and depth, in the positive semi-axis. Concerning the coccolithophores, there is a strong opposition between the group formed by $G$. flabellatus, $S$. lamina and $R$. sessilis, with positive loadings, and the SG (D. tubifera and Umbellosphaera spp.), with negative ones. F. profunda, Ophiaster spp. and Oolithotus spp., which integrate the DG are also in opposition with the SG, although presenting general lower loadings. The affinity among taxa belonging to the IG is also inferred by this figure analysis. Positive correlations between the SG and temperature, as well as dissolved oxygen are disclosed. The same is established between the groups DG and TDG and the variables density, nutrients and depth. With much lower variance CCA 2 reflects the influence of salinity and fluorescence, in its negative semi-axis. Along it the groups SG and TDG plus $R$. sessilis (positive loadings) are kept relatively separated from the IG and DG groups, confirming its usefulness as a discriminating tool.

\section{Discussion}

\subsection{Environmental controls on coccolithophore species distribution}

A total of 39 taxa were observed in the samples off Cabo Verde, from which only 16 were considered relevant for the present study. In the upper water column of this oligo-to -mesotrophic region the standing crop of coccolithophores was relatively low, with the maximum total cell densities reaching $30 \times 10^{3}$ cell $\mathrm{L}^{-1}$ in the southeastern slope of the Senghor seamount (Sg3). In addition, cell densities were also significant at the Senghor top (Sg2) and at the Eddy station (Ed) (Fig. 4). Comparatively, maximum coccolithophore abundance off the Madeira archipelago, also in the northeast subtropical Atlantic, was found to be four times higher (Narciso et al., 2019). Cabo Verde's relatively low 


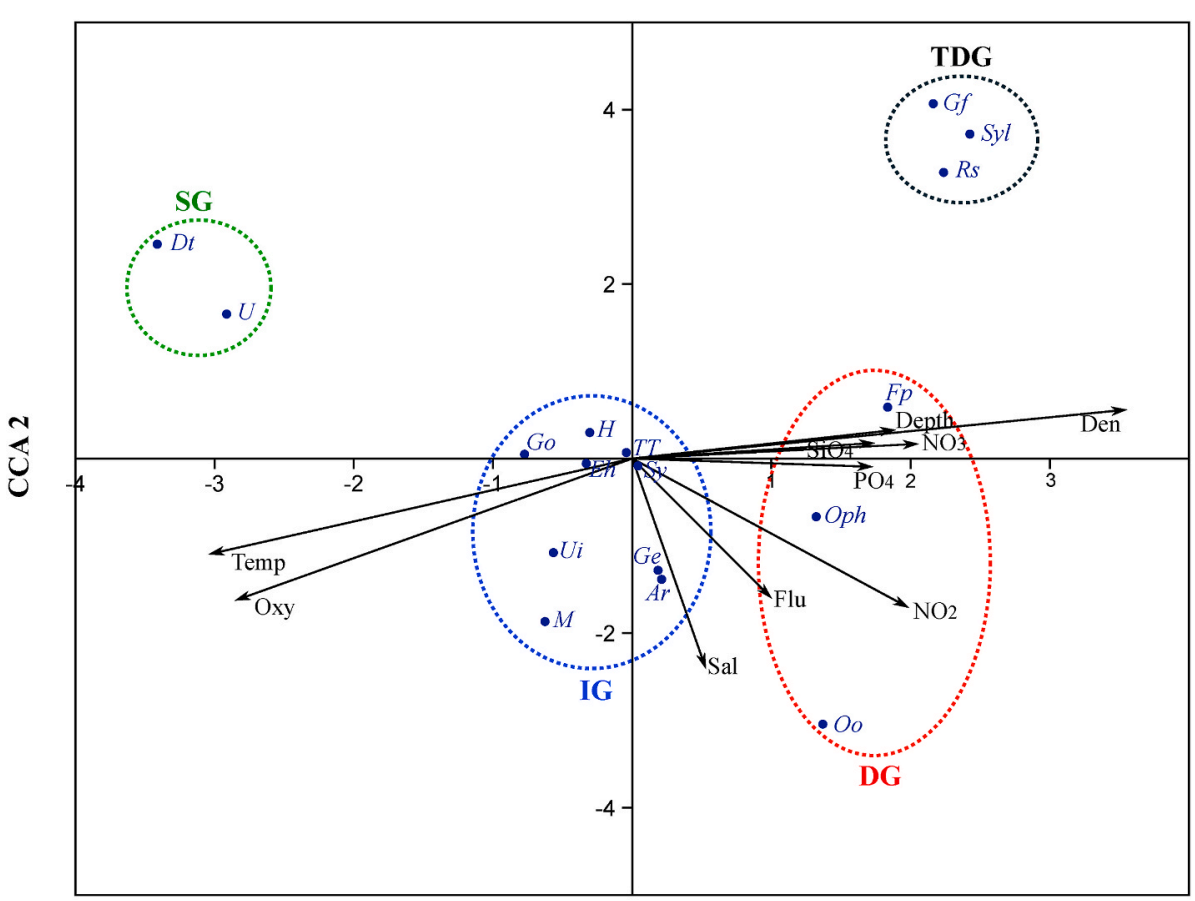

Fig. 6. CCA ordination diagram performed on Cabo Verde data set for the coccolithophore data. Environmental variables are indicated by vectors; Dendensity, Flu-fluorescence, Oxy-dissolved oxygen, Salsalinity, Temp-temperature, $\mathrm{NO}_{2^{-}}$nitrate, $\mathrm{NO}_{3^{-}}$nitrite, $\mathrm{PO}_{4}$ - phosphate, $\mathrm{SiO}_{4}$ - silicate. Taxa are represented by their initials; Ar- A. robusta, Dt- D. tubifera, Eh- E. huxleyi, Fp- F. profunda, Gf- G. flabellatus, GoG. oceanica, H-Helicosphaera spp., M- Michaelsarsia spp., Oo- Oolithotus spp., Oph- Ophiaster spp., RsR. sessilis, Ge- G. ericsonii, Sy- Syracosphaera spp., SylS. lamina, TT- Total, U- Umbellosphaera spp., UiUmbilicosphaera spp. Dashed ellipses gather the most closely resembling taxa; Shallow Group in green, Intermediate Group in blue, Deep Group in red, and The Deepest Group in black. (For interpretation of the references to colour in this figure legend, the reader is referred to the Web version of this article.)

\section{CCA 1}

Table 4

Eigenvalues and respective percentage variance in the CCA analysis performed on Cabo Verde data set.

\begin{tabular}{lll}
\hline CCA & Eigenvalue & $\%$ variance \\
\hline 1 & 0.12 & 72.36 \\
2 & 0.03 & 16.18 \\
3 & 0.02 & 5.68 \\
\hline
\end{tabular}

coccolithophore cell densities, with the lowest observed at the southernmost station S2 (Fig. 4), are in accordance with the regional seasonal variability in coccolithophore fluxes, with minima during fall (Köbrich and Baumann, 2009; Köbrich et al., 2015). Although the southernmost stations could have been influenced by the Guinea Dome during the surveyed interval, our data did not reveal any significant contribution of this submarine geomorphological structure to the coccolithophore stock in the region. In closer detail, Cabo Verde coccolithophore distribution showed hydrographic controls on the distribution of some of the major taxa; temperature, dissolved oxygen, density, nitrate and nitrite had the greatest influence on the assemblage variance (Fig. 6). The assemblage was dominated by E. huxleyi and G. oceanica, with a contribution of $56 \%$, followed by $F$. profunda. These results are similar with previous trap studies in the region (Köbrich and Baumann, 2009; Guerreiro et al., 2019), however, these always refer the preponderance of $F$. profunda over $G$. oceanica. In fact, the high abundances of $G$. oceanica found in the present work are mostly due to station Ed contribution (Fig. 5). Initially detected from geostrophic currents, oceanographic data confirmed the occurrence at that time of a cyclonic eddy, which was the reason behind

Table 5

Scores of the taxa, environmental variables and samples obtained in the CCA analysis performed on Cabo Verde data set.

\begin{tabular}{|c|c|c|c|c|c|c|c|c|c|c|c|c|c|c|}
\hline & CCA1 & CCA2 & & CCA1 & CCA2 & & CCA1 & CCA2 & & CCA1 & CCA2 & & CCA1 & CCA2 \\
\hline TT & -0.063 & 0.110 & $\mathbf{N}$ & 0.081 & 0.173 & SG & -0.102 & -0.251 & ED & -0.095 & -0.213 & $S$ & -0.899 & 0.457 \\
\hline Eh & -0.338 & -0.044 & $\mathbf{N}$ & 0.076 & 0.167 & SG & 0.416 & -0.203 & ED & 0.219 & 0.026 & $S$ & -0.160 & 0.200 \\
\hline sG & 0.201 & -1.291 & $\mathbf{N}$ & -0.598 & 0.121 & SG & 0.514 & 0.292 & ED & 0.497 & 0.204 & $S$ & 0.195 & -0.060 \\
\hline Go & -0.773 & 0.075 & $\mathbf{N}$ & -0.544 & 0.067 & SG & 0.382 & 0.233 & ED & 0.232 & 0.281 & $S$ & 0.519 & 0.577 \\
\hline Rs & 2.240 & 3.284 & $\mathbf{N}$ & -0.452 & 0.049 & SG & 0.175 & 0.029 & ED & 0.199 & 0.213 & $\mathbf{S}$ & 0.617 & 0.423 \\
\hline $\mathrm{Ar}$ & 0.199 & -1.322 & $\mathbf{N}$ & 0.204 & -0.155 & SG & 0.020 & 0.091 & ED & -0.184 & -0.042 & $S$ & 0.537 & 0.589 \\
\hline Dt & -3.420 & 2.491 & $\mathbf{N}$ & 0.358 & -0.142 & SG & -0.560 & 0.082 & SE & -0.645 & 0.195 & $S$ & 0.326 & 0.395 \\
\hline Fp & 1.824 & 0.580 & $\mathbf{N}$ & 0.479 & 0.362 & SG & 0.023 & -0.332 & SE & -0.355 & -0.066 & $S$ & -0.131 & -0.082 \\
\hline Gf & 2.151 & 4.081 & $\mathbf{N}$ & 0.236 & -0.048 & SG & 0.360 & -0.337 & SE & 0.272 & -0.131 & Depth & 0.374 & 0.065 \\
\hline $\mathbf{H}$ & -0.300 & 0.302 & $\mathbf{N}$ & 0.025 & -0.092 & SG & 0.483 & -0.182 & SE & 0.651 & 0.451 & Temp & -0.594 & -0.220 \\
\hline Oo & 1.187 & -3.192 & $\mathbf{N}$ & -0.023 & 0.023 & SG & 0.509 & 0.138 & SE & 0.440 & 0.228 & Sal & 0.095 & -0.458 \\
\hline Oph & 1.324 & -0.665 & $\mathbf{N}$ & -0.416 & 0.047 & SG & 0.081 & -0.236 & SE & 0.285 & 0.047 & Flu & 0.200 & -0.306 \\
\hline M & -0.632 & -1.897 & $\mathbf{N}$ & -0.285 & -0.140 & SG & -0.560 & 0.062 & SE & -0.154 & -0.044 & Den & 0.706 & 0.112 \\
\hline Sy & 0.047 & -0.090 & $\mathbf{N}$ & -0.094 & -0.364 & SG & 0.053 & -0.396 & SE & -0.104 & -0.054 & Oxy & -0.577 & -0.333 \\
\hline Syl & 2.427 & 3.715 & $\mathbf{N}$ & 0.216 & -0.342 & SG & 0.578 & 0.022 & $S$ & -1.154 & 0.587 & $\mathrm{SiO}_{4}$ & 0.344 & 0.036 \\
\hline $\mathbf{U}$ & -2.761 & 1.295 & $\mathbf{N}$ & 0.447 & -0.110 & SG & 0.426 & 0.071 & $S$ & -0.527 & -0.092 & $\mathrm{PO}_{4}$ & 0.341 & -0.019 \\
\hline Ui & -0.570 & -1.048 & $\mathbf{N}$ & 0.521 & 0.155 & SG & 0.339 & 0.164 & $S$ & 0.005 & -0.137 & $\mathrm{NO}_{2}$ & 0.393 & -0.338 \\
\hline $\mathbf{N}$ & -0.332 & -0.080 & $\mathbf{N}$ & 0.223 & 0.188 & SG & 0.138 & 0.239 & $S$ & 0.518 & 0.211 & $\mathrm{NO}_{3}$ & 0.402 & 0.036 \\
\hline $\mathbf{N}$ & -0.349 & -0.060 & $\mathbf{N}$ & 0.054 & -0.237 & SG & 0.031 & -0.157 & $S$ & 0.659 & 0.296 & & & \\
\hline $\mathbf{N}$ & -0.163 & -0.215 & $\mathbf{N}$ & -0.204 & 0.077 & SG & -0.027 & -0.007 & $S$ & 0.563 & 0.317 & & & \\
\hline $\mathbf{N}$ & 0.483 & 0.267 & SG & -0.640 & 0.144 & ED & -0.500 & 0.063 & $S$ & -0.067 & 0.093 & & & \\
\hline $\mathbf{N}$ & 0.152 & -0.048 & SG & -0.452 & 0.043 & ED & -0.467 & -0.020 & $S$ & -0.165 & -0.029 & & & \\
\hline
\end{tabular}


the recovery of water samples at station Ed (Christiansen et al., 2016). However, with well-marked oceanographic features in higher depths, the presence of the eddy is not obvious from the uppermost water column hydrographic data. A typical feature of this region is the presence of large eddies that seed near the coast and propagate offshorewards, keeping inside water mass that retains its physico-chemical properties. Known for dominating the coastal coccolithopore communities (e.g. Andruleit et al., 2000; Guerreiro et al., 2014; Narciso et al., 2016; 2019), G. oceanica may have been trapped inside the eddy, being transported through the currents and continuing to thrive until abnormal high values that are not matched by any other station. At same time, the development of this cold-core eddy surely led to significant nutrient enrichment in the euphotic zone around its perimeter (see Fig. 3), contributing to the maximum fluorescence peak at the Ed station (Fig. 2). The synchronous nutrient decrease during the chl- $a$ peak may reflect the rapid growth and uptake capacity of some phytoplankton organisms within relatively nutrient-rich and turbulent environment.

E. huxleyi was the most abundant species present off Cabo Verde, although it was found in relatively low absolute cell numbers compared to much higher cell concentrations reported from the high nutrient systems. This species is usually linked to productive water mass conditions, as well as upwelling regimes (e.g. Silva et al., 2009; Guerreiro et al., 2013; Ausín et al., 2018). A cosmopolitan and opportunistic behavior is also associated to E. huxleyi, since it may dominate the coccolithophore flora during most of the year, through high and low productive periods (Winter et al., 1994; Baumann et al., 2000; Andruleit, 2007). Thus, the low E. huxleyi abundances found in our samples may indicate a region slightly reduced in nutrient concentration, due to the almost non-existent migration of nutrient-enriched filaments from the coast, during the surveyed interval. Although eddies are features typically associated with upwelling systems, which dynamics may act as a trigger to costal filaments (Barton et al., 2004; Meunier et al., 2010, 2012), there are no evidences in our data showing that. In the Mauritania-Senegalese upwelling zone $\left(12-19^{\circ} \mathrm{N}\right)$, upwelling occurs during the winter months and fades during the summer months, related to the seasonal migration of the trade winds (Cropper et al., 2014). In addition, and based on sea surface temperature upwelling indices, the downwelling regime is also present in November, when the NE trade winds are still weak and the ITCZ in a northern position. So, during the surveyed interval (late fall) we may facing a transition to upwelling conditions, which reach their peak later in February. The dominance of E. huxleyi type A over type B in our study corroborates that there is no influence of upwelling extensions from the northwest African coast, since morphotype type A shows a preference for warm waters with low nutrient conditions (Findlay and Giraudeau, 2000; Mohan et al., 2008; Patil et al., 2017). This fact is also consistent with previous observations of Lathuilière et al. (2008). Also with high affinity for warm and highly-stratified water column, but living in the surface layer, is Umbellosphaera spp. (Kinkel et al., 2000; Haidar and Thierstein, 2001; Poulton et al., 2017). In our study, the high abundances of Umbellosphaera spp. and D. tubifera characterize the shallower and mixed layer of the well-stratified water column from the surveyed area. The notable negative correlation between the cell densities of these taxa and the nutrient concentration (Fig. 6), clearly demonstrates that Umbellosphaera spp. and D. tubifera are adapted to low nutrients, consistent with the observations of Baumann et al. (2008).

Oligotrophic regions tend to be favorable to species living close to the nutricline. F. profunda is known for its high affinity for warm and highly-stratified conditions characteristic of tropical and subtropical open-ocean regions (Kinkel et al., 2000; Haidar and Thierstein, 2001; Poulton et al., 2017), indicating the vicinity of the nutricline (Winter and Siesser, 1994; Kinkel et al., 2000). At the present study, F. profunda pattern is rather consistent with these remarks. In addition, during the surveyed time interval, $F$. profunda may have benefited from low irradiance, since this species is apparently adapted to low light conditions (Quinn et al., 2005). Furthermore, its habitat close to the nutricline would have provided the required nutrients during this time of lower nutrient input. The position of G. flabellatus, S. lamina and R. sessilis in the ordination diagram, opposite to the SG, shows they are typically deep-living species. The high affinity displayed among $F$. profunda, Ophiaster spp. and Oolithotus spp. shows their preference for cooler and deeper waters, as well as nutrients availability. Concerning the taxa positioned around the central zone of the diagram, namely Syracosphaera spp. and Helicosphaera spp., the environmental control for their distribution is complex. Syracosphaera is the most diverse genus, including species reported from different zones and various ecological habitats (Jordan and Chamberlain, 1997; Dimiza et al., 2008). In this study, coccospheres of 12 Syracosphaera species were recorded, justifying the ambiguous interpretation related to these taxa. Helicosphaera spp. are known to have a clear affinity for mesotrophic conditions in a well-mixed upper water column (Haidar and Thierstein, 2001; Ziveri et al., 2004; Boeckel et al., 2006). However, and despite the low significance of the loadings, the present data reveal a link to warm and low nutrient concentration. The same observation was reported in Guerreiro et al. (2019), based on a site positioned close to our study's region, during a stable and thermally stratified water column. Umbilicosphaera is also a genus that causes some controversy. On one hand it is known for its affinity for warm and oligotrophic habitats (Winter and Siesser, 1994; Baumann et al., 2016; Liu et al., 2018), which is evidenced in the CCA biplot. On the other hand it is influenced by water-mass stratification and nutrient level (Baumann et al., 2008), being also known for its preference for mesotrophic conditions (Hagino and Okada, 2006; Narciso et al., 2016, 2019). G. ericsonii shows a positive correlation with salinity, fluorescence and nitrate. If on one hand this taxon has ecological demands similar to E. huxleyi (Haidar and Thierstein, 2001), on the other hand prefers subsurface waters with enhanced nutrient concentrations (Baumann et al., 2008), which is closer to our findings. Positioned next to G. ericsonii in the CCA diagram, A. robusta reveals similar ecological affinities with this species, being associated to moderate productive zones (Narciso et al., 2019), from deeper (Takahashi and Okada, 2000; Andruleit, 2007) to shallower depths (Jordan and Winter 2000; Malinverno et al., 2003). Michaelsarsia spp. is mostly correlated with salinity, oxygen and temperature, and is known for its preference for moderate productive zones (Narciso et al., 2019), as well as shallower near-shore zones with dissolved oxygen increase trends, generally warm and moderately high-salinity environments (Agbali, 2014).

\subsection{Coccolithophore depth distribution}

The sampling resolution performed off Cabo Verde, along with the inferred well-stratified water column, allowed the identification of typical depth-related assemblages from the depth-distribution of the species. In subtropical waters, this common vertical separation of coccolithophore assemblages allows the recognition of two main photic zones: Upper Photic Zone (UPZ) and Lower Photic Zone (LPZ). Several studies refer the upper $80 \mathrm{~m}$ as the UPZ depth range (Winter et al., 1994; Jordan and Chamberlain, 1997) and the depth below 80-100 m (Baumann et al., 2008; Cortés et al., 2001) or even $120 \mathrm{~m}$ for the LPZ (Winter et al., 1994; Jordan and Chamberlain, 1997). However, these typical depth ranges are in fact coarse approaches, since local conditions cause significant variations in the actual zonal boundaries. Since the LPZ is commonly characterized by the dominance of F. profunda, we may consider that in the surveyed region off Cabo Verde, and during the late fall, the LPZ was in a higher position and, consequently, narrowing the UPZ ( $\sim$ the upper $60 \mathrm{~m}$ ). Thus, in the surveyed UPZ two distinct assemblages or groups could be recognized: a shallow one and an intermediate. Typical members of the SG, thriving mainly between 10 and 30 $\mathrm{m}$ of the mixed layer above the thermocline, were $D$. tubifera and Umbellosphaera spp. The assemblage part of the IG, characteristic from the $40-50 \mathrm{~m}$, was formed by the three placolith-bearing species E. huxleyi, G. ericsonii and G. oceanica, and by A. robusta, Helicosphaera 
spp., Michaelsarsia spp., Syracosphaera spp. and Umbilicosphaera spp. Some of these taxa are already known to occupy lower water depths, being associated with the middle photic zone (MPZ, between 70/80 m and 100/125 m; Jordan and Chamberlain, 1997; Jordan and Winter 2000; Cortés et al., 2001) or even with the LPZ, such as A. robusta (Jordan and Chamberlain, 1997; Hagino et al., 2000; Malinverno et al., 2003). Surprisingly, A. robusta seemed to be quite well adapted to the oceanographic conditions at 40-50 m depth, showing high related relative abundances (65\%, Table 3 ). However, it is important to refer that the optimal depth-range of the species may vary seasonally, especially when surface water stratification is more pronounced (e.g. Reid, 1980). Within the LPZ, two more distinct assemblages could be recognized: a deep one and the deepest. Typical members of the DG, which was representative of the $60-75 \mathrm{~m}$ water depth and of the nutricline level, were $F$. profunda, Ophiaster spp., Oolithotus spp. and R. sessilis. These taxa are well known as low photic dwellers, but from lower depths. However, and according to Cheng and Wang (1998), these species may thrive better when the water column above is clear and the mixed layer is shallow, conditions observed in the current study. Concerning $F$. profunda, probably the best known deep-living species, there was not a clear dependence showing that it could only live within a rather specific depth range. Although this species dominated in this 60-75 m depth interval (42\%, see Table 3), the second highest F. profunda absolute abundances were observed around $50 \mathrm{~m}$ depth, associated with the top and the southeastern slope of the Senghor seamount. The single $50 \mathrm{~m}$ peak of $F$. profunda observed in the station Sg3 may be explained by the associated shallower nutricline (Fig. 3). At the same time, the shoaling of the nutricline may have been responsible for the increase in E. huxleyi and G. ericsonii, which in turn increased the total absolute abundances. Under these circumstances, a thicker mixing layer (down to $50 \mathrm{~m}$; see Fig. 2) is acceptable but also tricky, since it is the limit for the more important cell concentrations of $F$. profunda. The highest coccolithophore densities recorded in the SE slope of the
Senghor seamount, as well as over the top, demonstrate the strong influence of this topographic feature on the development of this phytoplankton group. The shallower depth range found for $F$. profunda is consistent to what is described in Andruleit et al. (2003). Regarding to O. antillarum, similar depths were also found in previous works (Hagino et al., 2000; Andruleit et al., 2003) with the first putting this species below the thermocline, and the latter at the thermocline. The deepest assemblage, characteristic from depths below $80 \mathrm{~m}$, was formed by G. flabellatus and S. lamina, consistent with the descriptions of Knappertsbusch (1993), Jordan and Chamberlain (1997), Malinverno et al. (2003), among others.

Following a different approach, Poulton et al. (2017) proposed the existence of three floral groups to describe the vertical distribution of coccolithophores in the Atlantic subtropical gyres, equatorial and temperate waters. Thus, and based on surface irradiance, these authors considered a different terminology: Upper Euphotic Zone (UEZ, $>10 \%$ surface irradiance); Lower Euphotic Zone (LEZ, 10-1\% surface irradiance); and Sub-Euphotic Zone (SEZ, $<1 \%$ surface irradiance). Fig. 7 shows the position of our typical groups/assemblages against optical and percentage irradiance depths. For its construction we assumed that the deep chlorophyll/fluorescence maximum (DCM) approximates the depth of $1 \%$ surface irradiance (optical depth $=4.6$; see description in Poulton et al., 2017). Considering our data (Fig. 2), a DCM at $50 \mathrm{~m}$ depth was applied. Actually, this depth is closer to the ones observed around the tropical Equator (50-60 m; Monger et al. (1997); Poulton et al. (2006)) than the ones generally accepted for the subtropical gyres ( 105, Pérez et al., 2006; $\sim 125$ m, Poulton et al., 2006). However, it should be noted that: (i) Cabo Verde archipelago is very close to the province border of equatorial waters; (ii) the nutricline becomes increasingly shallower towards the east, when analyzing an E-W Atlantic transect (Guerreiro et al., 2019); (iii) and the nutricline during fall should present a relatively shallower position, since the deepening of the nutricline reach its maximum during the summer in consequence of

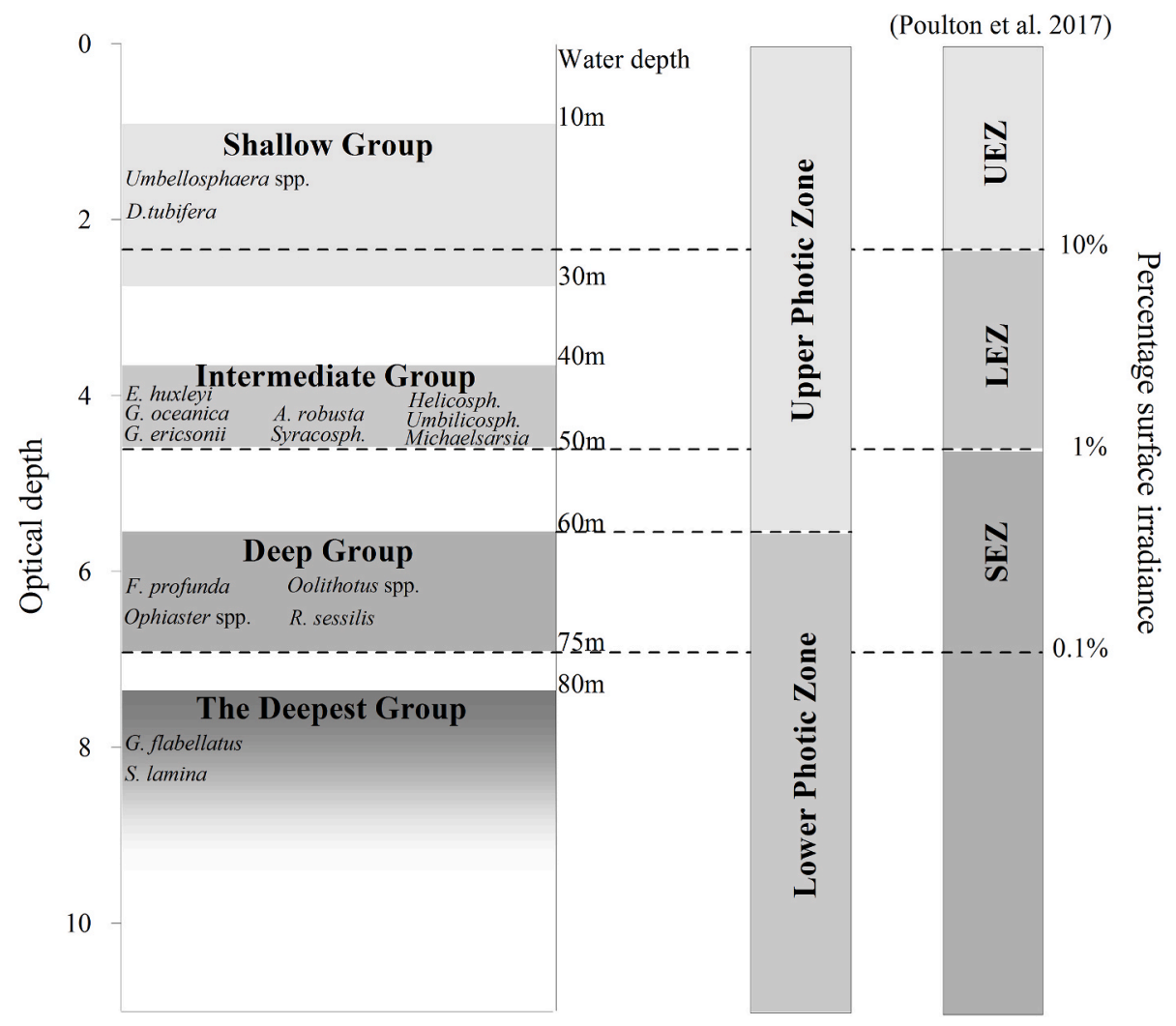

Fig. 7. Typical depth-related groups from Cabo Verde in the main photic zones and against optical and percentage irradiance depths. UEZ-Upper Euphotic Zone; LEZLow Euphotic Zone; SEZ- Sub-Euphotic Zone. 

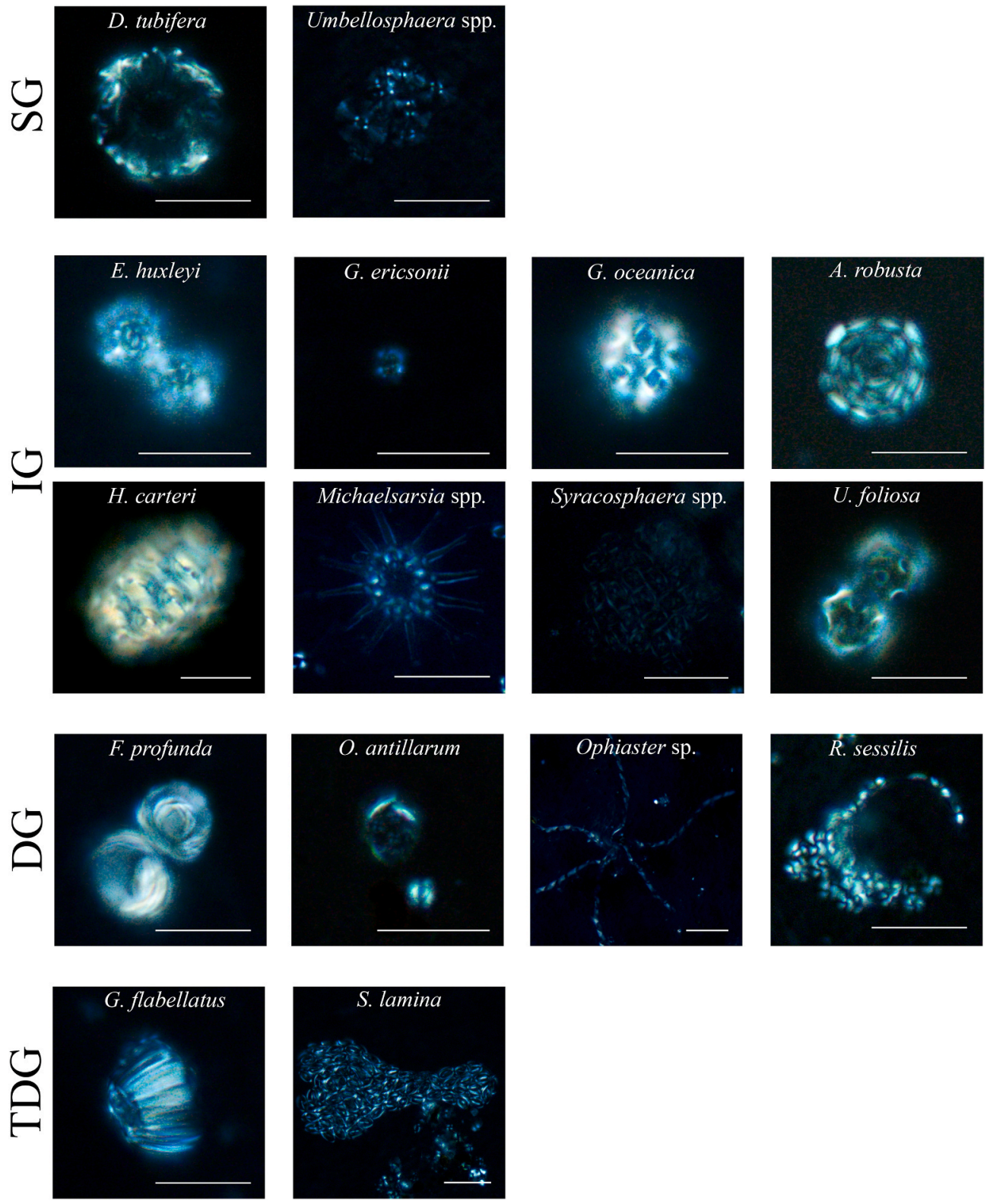

Fig. 8. Cross-polarized light microscopy images of the depth-related coccolithophore assemblages (all scale-bars are $10 \mu \mathrm{m}$ ).

maximum thermal stratification (Cermeño et al., 2008). The depth distribution of Cabo Verde floral assemblages is rather consistent with the floral groups described in Poulton et al. (2017), with just few discrepancies like the position of the shallow group. However, in the Equatorial context these authors also place the lower limit of the UEZ floral assemblage below $10 \%$ of the surface irradiance, similar to the position occupied by the SG (see Fig. 7). The maximum abundance of G. flabellatus well below $F$. profunda, as well as below the $0.1 \%$ of the surface irradiance, was also found by the previous authors and brings questions about the nutritional strategies of such kind of species. The existence of mixothrophy that combine photoautotrophy and phagotrophy is a theory that has been defended by several authors (e.g. Billard and Inouye, 2004; De Vargas et al., 2007; Poulton et al., 2017; Millán and Winter 2019) and recently proven by Avrahami and Frada (2020).

\section{Conclusions}

The present study on biodiversity and on spatial and vertical distributions of coccolithophores off Cabo Verde archipelago led to the following main conclusions:

1. A total of 39 taxa were observed, from which only 16 were considered relevant for the present study. E. huxleyi and G. oceanica were the dominant species, followed by $F$. profunda;

2. Total cell densities were relatively low, reaching to a maximum of 30 $\times 10^{3}$ cell $\mathrm{L}^{-1}$. The highest coccolithophore standing stock was found in the upper $50 \mathrm{~m}$ over the Senghor seamount, especially over its southeastern slope;

3. The high abundances of G. oceanica were mainly due to the Eddy station contribution. The formation of this eddy near the African coast may have trapped the coccolithophore community dominated by $G$. oceanica, promoting its transport and thriving offshorewards;

4. Four typical depth-related groups were observed: (i) a Shallow oligotrophic (10-30 m), represented by D. tubifera and Umbellosphaera spp.; (ii) an Intermediate $(40-50 \mathrm{~m})$, formed by the three placolith-bearing species E. huxleyi, G. ericsonii and G. oceanica, and by A. robusta, Helicosphaera spp., Michaelsarsia spp., Syracosphaera spp. and Umbilicosphaera spp.; (iii) a Deep (60-75 m) with 
F. profunda, Ophiaster spp., Oolithotus spp. and R. sessilis as typical members; (iv) and The Deepest ( $>80 \mathrm{~m}$ ), composed by $G$. flabellatus and S. lamina;

5. An overall shallowing of the entire coccolithophore community, with the UPZ compressed within the first $60 \mathrm{~m}$. Both the UPZ and LPZ communities disclosed a clear subdivision into sub-communities each, with the UPZ subdivided into the Shallow and Intermediate groups and the LPZ subdivided into the Deep and The Deepest groups;

6. The coccolithophore distribution off Cabo Verde was essentially explained by the general relatively warm and nutrient-depleted waters in the region during the surveyed interval, in result of the weaker NE trade winds and associated northward migration of the ITCZ.

\section{CRediT authorship contribution statement}

Áurea Narciso: Conceptualization, Investigation, Methodology, Formal analysis, Data curation, (Coccolithophores), Writing - original draft, Visualization. Jamileh Javidpour: Investigation, Resources, Data curation, (Nutrients); Review \& Editing. Xupeng Chi: Investigation, Data curation, (Nutrients). Mário Cachão: Resources, Formal analysis, Writing - review \& editing. Manfred Kaufmann: Supervision, Resources, Data curation, (CTD), Investigation, Writing - review \& editing.

\section{Declaration of competing interest}

The authors declare that they have no known competing financial interests or personal relationships that could have appeared to influence the work reported in this paper.

\section{Acknowledgements}

This research was supported by the Madeira's Regional Agency for the Development of Research Technology and Innovation (ARDITI Agência Regional para o Desenvolvimento da Investigação Tecnologia e Inovação) through a post-doc fellowship to AN funded in the scope of the project M1420-09-5369-FSE-000001. AN and MK acknowledge the support by national funds through FCT - Foundation for Science and Technology within the scope of UIDB/04423/2020 and UIDP/04423/ 2020.

MC acknowledges the financial support FCT through UIDB/50019/ 2020-IDL. The authors are deeply grateful to the captain and the crew and collaborators of the RV Maria S. Merian, mission 49. Shiptime and associated financial support were provided by the DFG (grant MSM49 to Bernd Christiansen).

\section{Appendix-Taxonomic list}

Full bibliographic references can be found in Young et al. (2003). Acanthoica quattrospina Lohmann, 1903

Acanthoica maxima Heimdal in Heimdal and Gaarder (1981)

Algirosphaera robusta (Lohmann, 1902) Norris, 1984

Alisphaera sp. Heimdal, 1973

Braarudosphaera bigelowii (Gran and Braarud, 1935) Deflandre, 1947*

Calcidiscus leptoporus (Murray and Blackman, 1898) Loeblich and Tappan, 1978

Calciosolenia sp. Gran, 1912

Calciosolenia brasiliensis (Lohmann, 1902) Young et al., 2003.

Calciosolenia murrayi Gran, 1912

Ceratolithus cristatus Kamptner 1950 HET coccolithomorpha type sensu Young et al., 2003*

Coccolithus pelagicus subsp. pelagicus (Wallich, 1877) Schiller, 1930*

Coronosphaera mediterranea (Lohmann, 1902) Gaarder, in Gaarder and Heimdal (1977)
Coronosphaera binodata (Kamptner, 1927) Gaarder, in Gaarder and Heimdal (1977)

Discosphaera tubifera (Murray and Blackman, 1898) Ostenfeld, 1900

Emiliania huxleyi (Lohmann, 1902) Hay and Mohler, in Hay et al. (1967)

Florisphaera profunda Okada and Honjo, 1973

Gephyrocapsa ericsonii McIntyre and Bé, 1967

Gephyrocapsa muellerae Bréhéret, 1978

Gephyrocapsa oceanica Kamptner, 1943

Gladiolithus flabellatus (Halldal and Markali, 1955) Jordan and Chamberlain, 1993

Helicosphaera carteri (Wallich, 1877) Kamptner, 1954

Helicosphaera pavimentum Okada and McIntyre, 1977

Helicosphaera wallichii (Lohmann, 1902) Okada and McIntyre, 1977 Michaelsarsia sp. Gran, 1912

Michaelsarsia adriaticus (Schiller, 1930) Manton et al., 1984

Michaelsarsia elegans Gran 1912; emend. Manton et al., 1984

Oolithotus antillarum (Cohen, 1964) Reinhardt, in Cohen and Reinhardt (1968)

Oolithotus fragilis (Lohmann, 1912) Martini and Müller, 1972

Ophiaster sp. Gran, 1912

Ophiaster formosus Gran, 1912

Ophiaster hydroideus (Lohmann, 1903) Lohmann, 1913

Reticulofenestra sessilis (Lohmann, 1912) Jordan and Young, 1990

Rhabdosphaera sp. Haeckel, 1894

Rhabdosphaera xiphos (Deflandre and Fert, 1954) Norris, 1984

Rhabdosphaera clavigera Murray and Blackman, 1898

Solisphaera helianthiformis Bolmann et al., 2006*

Syracosphaera sp. Lohmann, 1902

Syracosphaera anthos (Lohmann, 1912) Janin, 1987

Syracosphaera azureaplaneta Young et al., 2018

Syracosphaera bannockii (Borsetti and Cati, 1976) Cros et al., 2000

Syracosphaera gaarderae (Okada and McIntyre, 1977) Keuter, Young and Frada, 2019

Syracosphaera histrica Kamptner, 1941

Syracosphaera lamina Lecal-Schlauder, 1951

Syracosphaera nodosa Kamptner, 1941

Syracosphaera ossa (Lecal, 1966) Loeblich and Tappan, 1968

Syracosphaera protrudens Okada and McIntyre, 1977

Syracosphaera pulchra Lohmann, 1902

Syracosphaera rotula Okada and McIntyre, 1977

Syracosphaera tumularis Sánchez-Suárez, 1990

Umbellosphaera sp. Paasche in Markali and Paasche (1955)

Umbellosphaera tenuis (Kamptner, 1937) Paasche, in Markali and

Paasche (1955)

Umbilicosphaera foliosa (Kamptner, 1963) Geisen in Sáez et al. (2003)

Umbilicosphaera hulburtiana Gaarder, 1970

Umbilicosphaera sibogae (Weber-van Bosse, 1901) Gaarder, 1970

\section{References}

Abecasis, D., Cardigos, F., Almada, F., Gonçalves, J.M.S., 2009. New records on the ichthyofauna of the gorringe seamount (northeastern atlantic). Mar. Biol. Res. 5, 605-611. https://doi.org/10.1080/17451000902729696.

Agbali, A., 2014. Investigations of the Ecology of Calcareous Nannoplankton and Nannofossils in the North-East Gulf of Mexico to Help Establish a Baseline for Environmental Impact Studies. Doctor of Philosophy Dissertation. Florida State University, College of Arts and Sciences.

Andruleit, H., 2007. Status of the Java upwelling area (Indian Ocean) during the oligotrophic northern hemisphere winter monsoon season as revealed by coccolithophores. Mar. Micropaleontol. 64, 36-51. https://doi.org/10.1016/j. marmicro.2007.02.001.

Andruleit, H.A., Von Rad, U., Bruns, A., Ittekkot, V., 2000. Coccolithophore fluxes from sediment traps in the northeastern Arabian Sea off Pakistan. Mar. Micropaleontol. 38, 285-308. https://doi.org/10.1016/S0377-8398(00)00007-4.

Andruleit, H., Stäger, S., Rogalla, U., Čepek, P., 2003. Living coccolithophores in the northern Arabian Sea: ecological tolerances and environmental control. Mar. Micropaleontol. 49, 157-181. https://doi.org/10.1016/S0377-8398(03)00049-5.

Ausín, B., Zúñiga, D., Flores, J.A., Cavaleiro, C., Froján, M., Villacieros-Robineau, N., Alonso-Pérez, F., Arbones, B., Santos, C., de la Granda, F., Castro, G., Abrantes, C., F, 
Eglinton, T.I., Salgueiro, E., 2018. Spatial and temporal variability in coccolithophore abundance and distribution in the NW Iberian coastal upwelling system. Biogeosciences 15, 245-262. https://doi.org/10.5194/bg-15-245-2018.

Avrahami, Y., Frada, M.J., 2020. Detection of phagotrophy in the marine phytoplankton group of the coccolithophores (Calcihaptophycidae, Haptophyta) during nutrientreplete and phosphate-limited growth. J. Phycol. 1-6. https://doi.org/10.1111/ jpy.12997.

Baker, A.R., Weston, K., Kelly, S.D., Voss, M., Streu, P., Cape, J.N., 2007. Dry and wet deposition of nutrients from the tropical Atlantic atmosphere: links to primary productivity and nitrogen fixation. Deep. Res. Part I Oceanogr. Res. Pap. 54 1704-1720. https://doi.org/10.1016/j.dsr.2007.07.001.

Barton, E.D., Arístegui, J., Tett, P., Navarro-Pérez, E., 2004. Variability in the Canary Islands area of filament-eddy exchanges. Prog. Oceanogr. 62, 71-94. https://doi. org/10.1016/j.pocean.2004.07.003.

Baumann, K.-H., Andruleit, H., Samtleben, C., 2000. Coccolithophores in the Nordic Seas: comparison of living communities with surface sediment assemblages. Deep Sea Res. Part II Top. Stud. Oceanogr. 47, 1743-1772. https://doi.org/10.1016/ S0967-0645(00)00005-9.

Baumann, K.-H., Boeckel, B., Čepek, M., 2008. Spatial distribution of living coccolithophores along an east- west transect in the subtropical South Atlantic J. Nannoplankt. Res. 30, 9-21.

Baumann, K.H., Saavedra-Pellitero, M., Böckel, B., Ott, C., 2016. Morphométrie, biogéographie et écologie des genres Calcidiscus et Umbilicosphaera dans l'Atlantique Sud. Rev. Micropaleontol. 59, 239-251. https://doi.org/10.1016/j. revmic.2016.03.001.

Beare, D., McQuatters-Gollop, A., van der Hammen, T., Machiels, M., Teoh, S.J., HallSpencer, J.M., 2013. Long-term trends in calcifying plankton and $\mathrm{pH}$ in the north sea. PloS One 8. https://doi.org/10.1371/journal.pone.0061175.

Bendif, E.M., Nevado, B., Wong, E.L.Y., Hagino, K., Probert, I., Young, J.R., Rickaby, R.E M., Filatov, D.A., 2019. Repeated species radiations in the recent evolution of the key marine phytoplankton lineage Gephyrocapsa. Nat. Commun. 10, 1. https://doi org/10.1038/s41467-019-12169-7.

Billard, C., Inouye, I., 2004. What's new in coccolithophore biology? In: Thierstein, H.R. Young, J.R. (Eds.), Coccolithophores: from Molecular Processes to Global Impact. Springer Verlag, pp. 1-29.

Boeckel, B., Baumann, K.-H., Henrich, R., Kinkel, H., 2006. Coccolith distribution patterns in South Atlantic and Southern Ocean surface sediments in relation to environmental gradients. Deep-Sea Res. Part I Oceanogr. Res. Pap. 53, 1073-1099. https://doi.org/10.1016/j.dsr.2005.11.006.

Bown, P.R., Lees, J.A., Young, J.R., 2004. Calcareous nannoplankton evolution and diversity through time. In: Thierstein, H.R., Young, J.R. (Eds.), Coccolithophores: from Molecular Process to Global Impact. Springer Verlag, Berlin, Germany, pp. 481-508. https://doi.org/10.1007/978-3-662-06278-4.

Cermeño, P., Dutkiewicz, S., Harris, R.P., Follows, M., Schofield, O., Falkowski, P.G., 2008. The role of nutricline depth in regulating the ocean carbon cycle. Proc. Natl. Acad. Sci. U.S.A. 105, 20344-20349. https://doi.org/10.1073/pnas.0811302106.

Cheng, X., Wang, P., 1998. Variations in late Quaternary upper ocean structure of Okinawa Trough: a nannofossil approach. Sci. China Earth Sci. 41, 290-296.

Christiansen, B., Buchholz, C., Buchholz, F., Chi, X., Christiansen, S., Denda, A., Fabrizius, E., Hauss, H., Hoving, H.J.T., Janßen, S., Kaufmann, M., Kronschnabel, A. Lischka, A., Lüskow, F., Martin, B., Merten, V., Silva, P., Pinheiro, N., Springer, B. Zankl, S., Zeimet, T., 2016. SEAMOX: the influence of seamounts and oxygen minimum zones on pelagic fauna in the eastern tropical atlantic, cruise No. MSM49 (MARIA S. MERIAN-berichte). https://doi.org/10.2312/cr.

Cortés, M.Y., Bollmann, J., Thierstein, H.R., 2001. Coccolithophore ecology at the HOT station ALOHA, Hawaii. Deep. Res. Part II Top. Stud. Oceanogr. 48, 1957-1981. https://doi.org/10.1016/S0967-0645(00)00165-X.

Cropper, T.E., Hanna, E., Bigg, G.R., 2014. Spatial and temporal seasonal trends in coastal upwelling off Northwest Africa, 1981-2012. Deep. Res. Part I Oceanogr. Res. Pap. 86, 94-111. https://doi.org/10.1016/j.dsr.2014.01.007.

Cros, L., Fortuño, J.-M., 2002. Atlas of northwestern mediterranean. Sci. Mar. 66, 7-182.

De Vargas, C., Aubry, M.-P., Probert, I.A.N., Young, J., 2007. Origin and Evolution of Coccolithophores : from Coastal Hunters to Oceanic Farmers, Evolution. Elsevier Academic Press.

Denda, A., Christiansen, B., 2014. Zooplankton distribution patterns at two seamounts in the subtropical and tropical NE Atlantic. Mar. Ecol. 35, 159-179. https://doi.org/ 10.1111/maec. 12065 .

Denda, A., Stefanowitsch, B., Christiansen, B., 2017a. From the epipelagic zone to the abyss: trophic structure at two seamounts in the subtropical and tropical Eastern Atlantic - Part II Benthopelagic fishes. Deep. Res. Part I Oceanogr. Res. Pap. 130, 78-92. https://doi.org/10.1016/j.dsr.2017.08.005.

Denda, A., Stefanowitsch, B., Christiansen, B., 2017b. From the epipelagic zone to the abyss: trophic structure at two seamounts in the subtropical and tropical Eastern Atlantic - Part I zooplankton and micronekton. Deep. Res. Part I Oceanogr. Res. Pap. 130, 63-77. https://doi.org/10.1016/j.dsr.2017.10.010.

Dimiza, M.D., Triantaphyllou, M.V., Dermitzakis, M.D., 2008. Seasonality and ecology o living coccolithophores in eastern mediterranean coastal environments ( Andros island, middle Aegean sea ). Micropaleontology 54, 159-175.

Doi, T., Tozuka, T., Yamagata, T., 2009. Interannual variability of the Guinea Dome and its possible link with the atlantic meridional mode. Clim. Dynam. 33, 985-998. https://doi.org/10.1007/s00382-009-0574-z.

D'Amario, B., Ziveri, P., Grelaud, M., Oviedo, A., Kralj, M., 2017. Coccolithophore haploid and diploid distribution patterns in the Mediterranean Sea : can a haplodiploid life cycle be advantageous under climate change ? J. Plankton Res. 39, 781-794. https://doi.org/10.1093/plankt/fbx044.
Fernandes, M.J., Lázaro, C., Santos, A.M.P., Oliveira, P., 2005. Oceanographic characterisation of the Cape Verde region using multisensor data. Eur. Sp. Agency, (Special Publ. ESA. SP 815-824.

Findlay, C., Giraudeau, J., 2000. Extant calcareous nannoplankton in the Australian Sector of the Southern Ocean (austral summers 1994 and 1995). Mar. Micropaleontol. 40, 417-439. https://doi.org/10.1016/S0377-8398(00)00046-3.

Frada, M., Young, J., Cachão, M., Lino, S., 2010. A guide to extant coccolithophores (Calcihaptophycidae, Haptophyta) using light microscopy. J. Nannoplankt. Res. 31, 58-112.

Gove, J.M., McManus, M.A., Neuheimer, A.B., Polovina, J.J., Drazen, J.C., Smith, C.R., Merrifield, M.A., Friedlander, A.M., Ehses, J.S., Young, C.W., Dillon, A.K.,

Williams, G.J., 2016. Near-island biological hotspots in barren ocean basins. Nat. Commun. 7, 1-8. https://doi.org/10.1038/ncomms10581.

Guerreiro, C., Oliveira, A., de Stigter, H., Cachão, M., Sá, C., Borges, C., Cros, L., Santos, A., Fortuño, J.-M., Rodrigues, A., 2013. Late winter coccolithophore bloom off central Portugal in response to river discharge and upwelling. Continent. Shelf Res. 59, 65-83. https://doi.org/10.1016/j.csr.2013.04.016.

Guerreiro, C., Sá, C., de Stigter, H., Oliveira, A., Cachão, M., Cros, L., Borges, C., Quaresma, L., Santos, A.I., Fortuño, J.-M., Rodrigues, A., 2014. Influence of the Nazaré Canyon, central Portuguese margin, on late winter coccolithophore assemblages. Deep Sea Res. Part II Top. Stud. Oceanogr. 104, 335-358. https://doi. org/10.1016/j.dsr2.2013.09.011.

Guerreiro, C.V., Baumann, K.H., Brummer, G.J.A., Korte, L.F., Sá, C., Stuut, J.B.W., 2019. Transatlantic gradients in calcifying phytoplankton (coccolithophore) fluxes. Prog. Oceanogr. 176 https://doi.org/10.1016/j.pocean.2019.102140.

Hagino, K., Okada, H., 2006. Intra- and infra-specific morphological variation in selected coccolithophore species in the equatorial and subequatorial Pacific Ocean. Mar. Micropaleontol. 58, 184-206. https://doi.org/10.1016/J.MARMICRO.2005.11.001.

Hagino, K., Okada, H., Matsuoka, H., 2000. Spatial dynamics of coccolithophore assemblages in the equatorial western-central Pacific ocean. Mar. Micropaleontol. 39, 53-72. https://doi.org/10.1016/S0377-8398(00)00014-1.

Haidar, A.T., Thierstein, H.R., 2001. Coccolithophore dynamics off Bermuda (N. Atlantic). Deep Sea Res. Part II Top. Stud. Oceanogr. 48, 1925-1956. https://doi. org/10.1016/S0967-0645(00)00169-7.

Hammer, Ø., Harper, D.A.T.a.T., Ryan, P.D., 2001. PAST: Paleontological statistics software package for education and data analysis. Palaeontol. Electron. 4 (1), 1-9. https://doi.org/10.1016/j.bcp.2008.05.025.

Hansen, H.P., Koroleff, F., 1999. Determination of nutrients, p. 159-228. In: Grasshoff, K., Kremling, K., Ehrhardt, M. (Eds.), Methods of Seawater Analysis, third ed. Wiley VCH Weinheim.

Hasegawa, D., Yamazaki, H., Lueck, R.G., Seuront, L., 2004. How islands stir and fertilize the upper ocean. Geophys. Res. Lett. 31, 2-5. https://doi.org/10.1029/ 2004GL020143.

Heywood, K.J., Barton, E.D., Simpson, J.H., 1990. The effects of flow disturbance by an oceanic island. J. Mar. Res. 48, 55-73. https://doi.org/10.1357/ 002224090784984623

Honjo, S., 1996. Fluxes of particles to the interior of the open oceans. In: Ittekkot, V. (Ed.), Particle Flux in the Ocean, Scope 57. Wiley \& Sons, Chichester, pp. 91-154.

Hood, E.M., Sabine, C.L., Sloyan, B.M. (Eds.), 2010. The GO-SHIP Repeat Hydrography Manual: A Collection of Expert Reports and Guidelines. IOCCP Report Number 14, ICPO Publication Series Number 134. Available online at. http://www.go-ship.org/ HydroMan.html.

Jordan, R.W., Chamberlain, A.H.L., 1997. Biodiversity among haptophyte algae. Biodivers. Conserv. 6, 131-152. https://doi.org/10.1023/A:1018383817777.

Jordan, R.W., Winter, A., 2000. Assemblages of coccolithophorids and other living microplankton off the coast of Puerto Rico during January-May 1995. Mar. Micropaleontol. 39, 113-130. https://doi.org/10.1016/S0377-8398(00)00017-7.

Jordan, R.W., Cros, L., Young, J.R., 2004. A revised classification scheme for living haptophytes. Micropaleontology 50, 55-79. https://doi.org/10.2113/50.Suppl_1.55.

Kaufmann, M., Springer, B., Krahmann, G., Christiansen, B., 2020. Physical oceanography during Maria S. Merian cruise MSM49. PANGAEA. https://doi.org/ 10.1594/PANGAEA.910346.

Kinkel, H., Baumann, K.H., Cepek, M., 2000. Coccolithophores in the equatorial Atlantic Ocean: response to seasonal and Late Quaternary surface water variability. Mar. Micropaleontol. 39, 87-112. https://doi.org/10.1016/S0377-8398(00)00016-5.

Knappertsbusch, M., 1993. Geographic distribution of living and Holocene coccolithophores in the mediterranean sea. Mar. Micropaleontol. 21, 219-247. https://doi.org/10.1016/0377-8398(93)90016-Q.

Köbrich, M.I., Baumann, K., 2009. Coccolithophore flux in a sediment trap off cape blanc (NW Africa). J. Nannoplankt. Res. 30, 83-96.

Köbrich, M.I., Baumann, K.-H., Fischer, G., 2015. Seasonal and inter-annual dynamics of coccolithophore fluxes from the upwelling region off Cape Blanc, NW Africa. J. Micropalaeontol. https://doi.org/10.1144/jmpaleo2014-024, 2014-024.

Lathuilière, C., Echevin, V., Lévy, M., 2008. Seasonal and intraseasonal surface chlorophyll-a variability along the northwest African coast. J. Geophys. Res. Ocean. 113, 2000-2004. https://doi.org/10.1029/2007JC004433.

Liu, H., Sun, J., Wang, D., Zhang, X., Zhang, C., Song, S., Thangaraj, S., 2018. Distribution of living coccolithophores in eastern Indian Ocean during spring intermonsoon. Sci. Rep. 8, 1-12. https://doi.org/10.1038/s41598-018-29688-w.

Malinverno, E., Ziveri, P., Corselli, C., 2003. Coccolithophorid distribution in the Ionian Sea and its relationship to eastern Mediterranean circulation during late fall to early winter 1997. J. Geophys. Res. 108, 8115. https://doi.org/10.1029/2002JC001346.

Marañón, E., Fernández, A., Mouriño-Carballido, B., Martínez-García, S., Teira, E., Cermeño, P., Chouciño, P., Huete-Ortega, M., Fernández, E., Calvo-Díaz, A. Morán, X.A.G., Bode, A., Moreno-Ostos, E., Varela, M.M., Patey, M.D., Achterberg, E. P., 2010. Degree of oligotrophy controls the response of microbial plankton to 
Saharan dust. Limnol. Oceanogr. 55, 2339-2352. https://doi.org/10.4319/ 10.2010.55.6.2339.

Mazeika, P.A., 1967. Thermal domes in the eastern tropical Atlantic Ocean. Limnol. Oceanogr. 12, 537-539.

Mendonça, A., Arístegui, J., Vilas, J.C., Montero, M.F., Ojeda, A., Espino, M., Martins, A., 2012. Is there a seamount effect on microbial community structure and biomass? the case study of Seine and Sedlo seamounts (Northeast Atlantic). PloS One 7. https:// doi.org/10.1371/journal.pone.0029526.

Meunier, T., Rossi, V., Morel, Y., Carton, X., 2010. Influence of bottom topography on an upwelling current: generation of long trapped filaments. Ocean Model. 35, 277-303. https://doi.org/10.1016/j.ocemod.2010.08.004.

Meunier, T., Barton, E.D., Barreiro, B., Torres, R., 2012. Upwelling filaments off cap blanc: interaction of the NW african upwelling current and the Cape Verde frontal zone eddy field? J. Geophys. Res. Ocean. 117, 1-18. https://doi.org/10.1029/ 2012JC007905.

Millán, J., Winter, A., 2019. Direct and indirect evidence of coccolithophores' Activity in the deep euphotic zone. J. Nannoplankt. Res. Abstr. 17th Ina Conf. Santos 77. Brazil.

Mittelstaedt, E., 1991. The ocean boundary along the northwest African coast: circulation and oceanographic properties at the sea surface. Prog. Oceanogr. 26, 307-355. https://doi.org/10.1016/0079-6611(91)90011-A.

Molinari, R.L., Garzoli, S.L., Katz, E.J., Harrison, D.E., Richardson, P.L., Reverdin, G., 1986. A synthesis of the first GARP global experiment (FGGE) in the equatorial atlantic ocean. Prog. Oceanogr. 16, 91-112.

Monger, B., McClain, C., Murtugudde, R., 1997. Seasonal phytoplankton dynamics in the eastern tropical Atlantic. J. Geophys. Res. Ocean. 102, 12389-12411. https://doi. org /10.1029/96JC03982.

Morato, T., Hoyle, S.D., Allain, V., Nicol, S.J., 2010. Seamounts are hotspots of pelagic biodiversity in the open ocean. Proc. Natl. Acad. Sci. Unit. States Am. 107, 9707-9711. https://doi.org/10.1073/pnas.0910290107.

Narciso, Á., Gallo, F., Valente, A., Cachão, M., Cros, L., Azevedo, E.B., Barcelos Ramos, J., 2016. Seasonal and interannual variations in coccolithophore abundance off Terceira island, Azores (central north atlantic). Continent. Shelf Res. 117, 43-56. https://doi.org/10.1016/j.csr.2016.01.019.

Narciso, Á., Caldeira, R., Reis, J., Hoppenrath, M., Cachão, M., Kaufmann, M., 2019. The effect of a transient frontal zone on the spatial distribution of extant coccolithophores around the Madeira archipelago (Northeast Atlantic). Estuar. Coast Shelf Sci. 223, 25-38. https://doi.org/10.1016/j.ecss.2019.04.014.

Narciso, A., Kaufmann, M., Springer, B., Christiansen, B., 2020. Extant coccolithophores around Cabo verde archipelago during Maria S. Merian cruise MSM49. PANGAEA. https://doi.org/10.1594/PANGAEA.914669.

Oviedo, A., Ziveri, P., Álvarez, M., Tanhua, T., 2015. Is coccolithophore distribution in the Mediterranean Sea related to seawater carbonate chemistry? Ocean Sci. 11, 13-32. https://doi.org/10.5194/os-11-13-2015.

Oviedo, A.M., Ziveri, P., Gazeau, F., 2017. Coccolithophore community response to increasing pCO2 in Mediterranean oligotrophic waters. Estuar. Coast Shelf Sci. 186, 58-71. https://doi.org/10.1016/j.ecss.2015.12.007.

Patil, S.M., Mohan, R., Shetye, S.S., Gazi, S., Baumann, K.H., Jafar, S., 2017. Biogeographic distribution of extant coccolithophores in the Indian sector of the southern ocean. Mar. Micropaleontol. 137, 16-30. https://doi.org/10.1016/j. marmicro.2017.08.002.

Pérez, V., Fernández, E., Marañón, E., Morán, X.A.G., Zubkov, M.V., 2006. Vertical distribution of phytoplankton biomass, production and growth in the Atlantic subtropical gyres. Deep. Res. Part I Oceanogr. Res. Pap. 53, 1616-1634. https://doi org/10.1016/j.dsr.2006.07.008.

Pérez-Rodríguez, P., Pelegrí, J.L., Marrero-Díaz, A., 2001. Dynamical characteristics of the Cape Verde frontal zone. Sci. Mar. 65, 241-250. https://doi.org/10.3989/ scimar.2001.65s1241.

Peterson, R.G., Stramma, L., 1991. Upper-level circulation in the south atlantic ocean. Prog. Oceanogr. 26, 1-73. https://doi.org/10.1016/0079-6611(91)90006-8.

Poulton, A.J., Sanders, R., Holligan, P.M., Stinchcombe, M.C., Adey, T.R., Brown, L., Chamberlain, K., 2006. Phytoplankton mineralization in the tropical and subtropical Atlantic Ocean. Global Biogeochem. Cycles 20, 1-10. https://doi.org/10.1029/ 2006 GB002712.
Poulton, A.J., Holligan, P.M., Charalampopoulou, A., Adey, T.R., 2017. Coccolithophore ecology in the tropical and subtropical Atlantic Ocean: new perspectives from the Atlantic meridional transect (AMT) programme. Prog. Oceanogr. 158, 150-170. https://doi.org/10.1016/j.pocean.2017.01.003.

Quinn, P.S., Cortés, M.Y., Bollmann, J., 2005. Morphological variation in the deep oceandwelling coccolithophore Florisphaera profunda (Haptophyta). Eur. J. Phycol. 40, 123-133. https://doi.org/10.1080/09670260400024667.

Reid, F.M.H., 1980. Coccolithophorids of the North Pacific Central Gyre with notes on their vertical and seasonal distribution. Micropaleontology 26, 151-176. https://doi. org/10.2307/1485436.

Romero, O., Baumann, K.-H., Zonneveld, K., Donner, B., Hefter, J., Hamady, B., Fischer, G., 2019. Variability of phyto- and zooplankton communities in the Mauritanian coastal upwelling between 2003 and 2008. Biogeosci. Discuss. 1-51. https://doi.org/10.5194/bg-2019-314.

Rost, B., Riebesell, U., 2004. Coccolithophores and the biological pump: responses to environmental changes. In: Thierstein, Hans R., Young, Jeremy R. (Eds.), Coccolithophores: from Molecular Process to Global Impact. Springer Verlag, Berlin, Germany, pp. 99-125. https://doi.org/10.1007/978-3-662-06278-4_5.

Schiebel, R., 2002. Planktic foraminiferal sedimentation and the marine calcite budget. Global Biogeochem. Cycles 16, 1-3. https://doi.org/10.1029/2001GB001459, 3-21.

Schlitzer, R., 2020. Ocean Data View. https://odv.awi.de.

Siedler, G., Zangenberg, N., Onken, R., 1992. Seasonal changes in the tropical atlantic circulation: observation and simulation of the Guinea Dome. J. Geophys. Res. 97, 703-715.

Silva, A., Palma, S., Oliveira, P.B., Moita, M.T., 2009. Composition and interannual variability of phytoplankton in a coastal upwelling region (Lisbon Bay, Portugal). J. Sea Res. 62, 238-249. https://doi.org/10.1016/j.seares.2009.05.001.

Smith, H.E.K., Poulton, A.J., Garley, R., Hopkins, J., Lubelczyk, L.C., Drapeau, D.T., Rauschenberg, S., Twining, B.S., Bates, N.R., Balch, W.M., 2017. The influence of environmental variability on the biogeography of coccolithophores and diatoms in the Great Calcite Belt. Biogeosciences 14, 4905-4925. https://doi.org/10.5194/bg14-4905-2017.

Stramma, L., Hüttl, S., Schafstall, J., 2005. Water masses and currents in the upper tropical northeast Atlantic off northwest Africa. J. Geophys. Res. 110, C12006. https://doi.org/10.1029/2005JC002939.

Takahashi, K., Okada, H., 2000. Environmental control on the biogeography of modern coccolithophores in the southeastern Indian Ocean offshore of Western Australia. Mar. Micropaleontol. 39, 73-86. https://doi.org/10.1016/S0377-8398(00)00015-3.

Taylor, A.R., Russell, M.A., Harper, G.M., Collins, T.f.T., Brownlee, C., 2007. Dynamics of formation and secretion of heterococcoliths by Coccolithus pelagicus ssp. braarudii. Eur. J. Phycol. 42, 125-136. https://doi.org/10.1080/09670260601159346.

Tyrrell, T., Young, J.R., 2009. Coccolithophores. Encyclopedia of Ocean Sciences. Elsevier, pp. 606-614. https://doi.org/10.1016/B978-012374473-9.00662-7.

Vangriesheim, A., Bournot-Marec, C., Fontan, A.C., 2003. Flow variability near the Cape Verde frontal zone (subtropical Atlantic Ocean). Oceanol. Acta 26, 149-159. https:// doi.org/10.1016/S0399-1784(02)00002-6.

Westbroek, P., Brown, C.W., Bleijswijk, J. van, Brownlee, C., Brummer, G.J., Conte, M., Egge, J., Fernández, E., Jordan, R., Knappertsbusch, M., Stefels, J., Veldhuis, M., van der Wal, P., Young, J., 1993. A model system approach to biological climate forcing. The example of Emiliania huxleyi. Global Planet. Change 8, 27-46. https://doi.org/ 10.1016/0921-8181(93)90061-R.

Winter, A., Siesser, W.G., 1994. Atlas of Living Coccolithophores, Coccolithophores. Cambridge University Press. https://doi.org/10.1017/S0025315400015496.

Young, J.R., 1994. Functions of coccoliths. In: Winter, A., Siesser, W.G. (Eds.), Coccolithophores. Cambridge University Press, New York, pp. 13-27.

Young, J., Geisen, M., Cros, L., Kleijne, A., Sprengel, C., Probert, I., Ostergaard, J., 2003. A guide to extant coccolithophore taxonomy. J. Nannoplankt. Res. Spec. Issue $1-121$.

Zenk, W., Klein, B., Schroder, M., 1991. Cape Verde frontal zone. Deep sea Res. Part I Oceanogr. Res. Pap. 38, S505-S530. https://doi.org/10.1016/s0198-0149(12) 80022-7.

Ziveri, P., Baumann, K.H., Böckel, B., Bollmann, J., Young, J.R., 2004. Biogeography of selected Holocene coccoliths in the atlantic ocean. In: Thierstein, H., Young, J. (Eds.), Coccolithophores: from Molecular Process to Global Impact, pp. 403-428. 